IZA DP No. 9831

The Effect of Medical Marijuana Laws on Labor Market Outcomes

Joseph J. Sabia

Thanh Tam Nguyen

March 2016 


\title{
The Effect of Medical Marijuana Laws on Labor Market Outcomes
}

\author{
Joseph J. Sabia \\ University of New Hampshire, San Diego State University \\ and IZA \\ Thanh Tam Nguyen \\ San Diego State University
}
Discussion Paper No. 9831
March 2016

\author{
IZA \\ P.O. Box 7240 \\ 53072 Bonn \\ Germany \\ Phone: +49-228-3894-0 \\ Fax: +49-228-3894-180 \\ E-mail: iza@iza.org
}

Any opinions expressed here are those of the author(s) and not those of IZA. Research published in this series may include views on policy, but the institute itself takes no institutional policy positions. The IZA research network is committed to the IZA Guiding Principles of Research Integrity.

The Institute for the Study of Labor (IZA) in Bonn is a local and virtual international research center and a place of communication between science, politics and business. IZA is an independent nonprofit organization supported by Deutsche Post Foundation. The center is associated with the University of Bonn and offers a stimulating research environment through its international network, workshops and conferences, data service, project support, research visits and doctoral program. IZA engages in (i) original and internationally competitive research in all fields of labor economics, (ii) development of policy concepts, and (iii) dissemination of research results and concepts to the interested public.

IZA Discussion Papers often represent preliminary work and are circulated to encourage discussion. Citation of such a paper should account for its provisional character. A revised version may be available directly from the author. 


\section{ABSTRACT \\ The Effect of Medical Marijuana Laws on Labor Market Outcomes*}

A number of recent studies have found that medical marijuana laws (MMLs) are associated with increased marijuana use among adults, in part due to spillover effects into the recreational market. This study is the first to explore the labor market consequences of MMLs. Using repeated cross-sections of the Current Population Survey from January 1990 to December 2014, we find that the enforcement of MMLs is associated with a 2 to 3 percent reduction in hourly earnings for young adult males. The effect is particularly pronounced when examining MMLs that include a collective cultivation provision. For women and older males, there is little evidence of adverse labor market effects of MMLs. We conclude that the health effects of MMLs may adversely affect labor market productivity of young males.

JEL Classification: J31, J38, I18

Keywords: medical marijuana laws, productivity, wages

Corresponding author:

Joseph J. Sabia

Department of Economics

San Diego State University

5500 Campanile Drive

San Diego, CA 92182-4485

USA

E-mail: jsabia@mail.sdsu.edu

\footnotetext{
* The authors thank Rosalie Pacula, Daniel Rees, Mark Anderson, and Peter Kuhn for useful comments on an earlier draft of this paper. We also thank participants at the 2014 Southern Economic Association and the 2015 Western Economics Association International's Pacific Rim Conference for useful comments and suggestions on an early draft of this paper. We also thank Glen Kirkpatrick and Oren Rosenberg for excellent research assistance.
} 


\section{Introduction}

Medical marijuana laws, which have been adopted by 23 states and the District of Columbia, legalize the possession, cultivation, and consumption of marijuana to treat medical conditions such as anxiety, nausea, joint problems, and the side effects of cancer or Human Immune Deficiency Syndrome treatments (Doblin and Kleinman 1991; Galuppo et al. 2014; Hall et al. 2005; Lotan et al. 2014; Naftali et al. 2013; Vinciguerra et al. 1988; Vu et al. 2013). While MMLs reduce the cost of obtaining marijuana for medical purposes via elimination of criminal penalties, there is also evidence that MMLs may impact the recreational market via supply-side reductions in the street price of high-grade marijuana (Anderson et al. 2013). ${ }^{1}$ Several studies have found that the enforcement of MMLs is associated with an increase in marijuana use among adults (Anderson and Rees 2011; Choi 2014; Wen et al. 2014), driven by some combination of medicinal and recreational use.

The effect of MMLs on labor supply and earnings is theoretically ambiguous. If MMLs allow individuals with physical or mental health ailments to effectively treat their conditions (Anderson et al. 2014; Sabia et al. Forthcoming), MMLs could increase labor supply and increase productivity among those employed. Moreover, if MMLs create employment opportunities in marijuana production and legitimate sales, this could increase labor supply. However, if MML-induced marijuana use induces lethargy (Delisle et al. 2010; Irons et al. 2014; Pesta et al. 2013), impedes cognition (Hanson et al. 2010), increases depression (Degenhardt et al. 2003; Green and Ritter 2000), or increases the returns to leisure time, this could decrease attachment to the labor force and reduce earnings. Moreover, if marijuana use acts as a gateway to harder drugs (Deza 2012; Mills and Noyes 1984; Miron 2005) or diminishes the acquisition of human capital (Chatterji 2003; Hall 2009) these effects could also adversely affect labor market

\footnotetext{
${ }^{1}$ See also Malivert and Hall (2014)
} 
productivity (Ashenfelter and Krueger 1994; Banerjee et al. 2013; Buchmueller and Zuvekas 1998; Frijters et al. 2010; Kandel and Davies 1990). In addition, if marijuana users face discrimination in the workplace (Wozniak 2012), this could be yet another mechanism through which MMLs could affect labor market outcomes.

MMLs may also indirectly affect labor market outcomes through their effects on alcohol consumption. If alcohol serves as a "social lubricant" that enhances labor market networking (Chatterji and DeSimone 2006; Peters 2009; Peters and Stringham 2006) and alcohol and marijuana are substitutes (Anderson et al. 2014; Crost and Guerrero 2012; Sabia et al. Forthcoming), MMLs may reduce employment or wages. On the other hand, if alcohol and marijuana are complements (Pacula et al. 2004; Pacula et al. 2013; Wen et al. 2014), or if MMLs reduce more severe problem drinking (Terza 2002), MMLs could increase in employment or wages.

Using repeated cross-sections of the Current Population Survey Outgoing Rotation Groups from January 1990 to December 2014, this study is the first to examine the relationship between MMLs and labor market outcomes. Our results suggest little consistent evidence that MMLs affect net employment or hours worked among employed individuals. However, we do find that enforcement of MMLs is associated with a 2.5 percent reduction in hourly wages for young men. These results are robust to the inclusion of controls for state-specific time-varying substance use policies, state-specific time trends, state-specific anti-marijuana legalization sentiment, and MML policy leads. Findings from synthetic control estimates, while much less precisely estimated, generally point to a similar pattern of results. For women and older males, there is little evidence of adverse labor market effects of MMLs. 
Possible mechanisms to explain an MML-induced decline in earnings among young men include (i) lethargy-inducing, cognitive-diminishing, or depressive effects of marijuana use, (ii) spillover effects of MMLs on alcohol consumption, and (iii) the resultant health effects on occupational mobility or job tenure. Supplemental analyses of the Behavioral Risk Factor Surveillance System surveys uncover some support for these mechanisms, but more research is necessary to uncover the precise channels at work.

\section{Background}

Between 2002 and 2013, illicit drug consumption amongst individuals ages 12 and older rose from 8.3 to 9.4 percent (SAMHSA 2014). This upturn was driven largely by an increase in marijuana consumption, which rose from 6.2 to 7.5 percent over the same period, with the largest increase occurring after 2008. Frequent marijuana use has also substantially increased in recent years. According to data from the National Survey of Drug Abuse and Health, in 2013, 8.1 million individuals ages 12 and older consumed marijuana on 20 or more days in the past month, representing a 58.8 percent increase from 2007. Among current (past month) marijuana users, over 40 percent were frequent users (SAMHSA 2014).

Employers' concerns about substance use-driven productivity losses and work absences have increased prevalence of on-the-job drug testing. According to Quest Diagnostics (2002, 2014), the number of drug test the company performed in the combined U.S. workforce increased from 6.3 million in 2001 to 8.5 million in 2013. In 2013, 7.5 million career urine drug tests cost nearly $\$ 150$ million. $^{2}$

\footnotetext{
${ }^{2}$ This estimate can be considered a lower-bound cost, as it does not account for spending on other forms of workforce drug tests such as hair tests and oral fluid tests, administrative costs to employers, or the costs to employers of outsourcing drug testing.
} 
While use of harder illicit drugs — such as cocaine, methamphetamine, and heroin — have been linked to adverse health (Chen and Lin 2009; Washton and Gold 1984; Washton and Tatarsky 1983), human capital (Chatterji 2003; Harder and Chilcoat 2007), and labor market outcomes (DeSimone 2002; French et al. 2001; Macdonald et al. 2003; Van Ours 2005), evidence on the consequences of marijuana use is more mixed. Some studies link marijuana use to poorer cognition (Hanson et al. 2010), increased incidence of lethargy (Delisle et al. 2010; Irons et al. 2014; Pesta et al. 2013), and heightened risk of depressive symptomatology (Harder et al. 2006; Van Ours and Williams 2011). There is also evidence that marijuana use may be positively related to later use of harder drugs (Deza 2012; Mills and Noyes 1984; Miron 2005), and diminished academic achievement (Chatterji 2003; Hall 2009). However, marijuana use has also been shown to have important medical benefits that are related to labor market performance. For instance, marijuana use has been found to be effective at reducing joint pain (Blake et al. 2005) and muscle aches (Fiz et al. 2011). Its consumption has also been found to improve appetite (Riggs et al. 2012; Soria-Gomez et al. 2014), and diminish nausea-related symptoms (Doblin and Kleinman 1991; Vinciguerra et al. 1988). Finally, marijuana use has also been linked to diminished anxiety (Marcel et al. 2007) and even reduced completed suicides (Anderson et al. 2014). Therefore - in part because marijuana can be consumed for both recreational and medicinal purposes - it is unclear how increases in its use may affect labor force participation and earnings.

Labor Market Effects of Substance Use. The key empirical challenge to estimating the labor market effects of illicit drug use is in addressing the endogeneity of drug use. To generate plausibly exogenous variation in drug consumption, several studies have relied on an instrumental variables (IV) approach. Gill and Michaels (1992) use prior illegal activity as an 
instrument for illicit drug use and found that drug users are less likely to be employed than their non-using counterparts. Zarkin et al. (1998) use (i) self-assessment of risk incurred by using drugs and (ii) perceived difficulty in finding illicit substances as instruments, and find that the relationship between marijuana use and hours of work varies widely (from large and positive to large and negative) across adjacent cross-sectional surveys. French et al. (2001) use religiosity as an instrument and find that chronic drug use is associated with a 9 percentage-point decline in employment, but light drug use has no effect. DeSimone (2002) uses cross-regional variation in illicit drug prices and cross-state marijuana decriminalization laws as instruments, and finds that marijuana use is associated with a 15 percent decline in employment, with cocaine use having a larger adverse effect. MacDonald and Pudney (2000) jointly model drug use and unemployment, and, using church attendance as an exclusion restriction. find that hard drug use is positively related to unemployment of British youths.

While researchers may argue about the exogeneity of these instruments-for instance, because (i) prior illegal behavior, risk assessment, or religiosity may be related to unobserved personal characteristics related to drug use (such as discount rates or personality) and (ii) crossregional price variation may capture demand-side characteristics of consumers that affect drug use - taken as a whole, this literature tends to point to adverse employment effects of drug use.

Evidence on the wage effects of illicit drug use is more mixed (Cawley and Ruhm 2012; Van Ours and Williams 2014). A review of the literature by Van Ours and Williams (2014) finds that in the pre-1998 literature, many studies pointed to a positive relationship between drug use and wages (at least for some demographic groups), while the "second wave" of the literature has generally found that "infrequent or non-problematic drug use has no impact on wages, whereas problematic use does have negative wage effects." (Van Ours and Williams 2014; p. 13). 
As in the employment literature, disentangling the effects of drug use from difficult-tomeasure correlates—such as ability—has proven challenging (Conti 2010). Van Ours (2006) uses (i) parental marijuana use and (ii) the presence of children in the household as instruments, in a discrete factor framework and finds that marijuana use is associated with a 10 percent reduction in wages among young men in Amsterdam. However, alternate estimation techniques — such as individual fixed effects models to control for fixed individual heterogeneity—suggest much smaller effects. ${ }^{3}$

Medical Marijuana Laws and Health. No study of which we are aware has estimated the effect of medical marijuana laws on labor market outcomes. However, a number of studies have examined the effect of MMLs on health outcomes that might be expected to affect labor market outcomes. Several studies show — using a difference-in-difference approach that exploits within-state over-time variation in the enforcement of MMLs for identification-that MMLs are associated with a 10 to 19 percent increase in marijuana use among adults (Anderson and Rees 2011; Choi 2014; Wen et al. 2014). In contrast, there is little evidence of spillover effects to those under age 20 (Anderson et al. 2015; Pacula et al. 2014; Wen et al. 2014).

Moreover, MML-induced increases in marijuana use among adults do not appear to come entirely from the medical market. Anderson et al. (2013) show that the enforcement of MMLsparticularly those that allow for collective cultivation of marijuana for multiple patients - is associated with a decline in the average street price of high-grade marijuana, which suggests that the supply-side effects of MMLs may spillover into the recreational market. Moreover, MMLinduced increases in marijuana use for younger demographic groups (such as young adult men), with relatively lower rates of medical conditions for which marijuana is designed to treat, further suggests the presence of recreational spillovers (Sabia et al. Forthcoming).

\footnotetext{
${ }^{3}$ See, for example, Kaestner (1994).
} 
Mechanisms to Explain a Link Between MMLs and the Labor Market. The effect of MML-induced increases in marijuana consumption on labor market outcomes is theoretically ambiguous. Sabia et al. (Forthcoming) find evidence that MMLs are associated with a decline in physical activity for younger individuals (those ages 18 to 34), consistent with the hypothesis that marijuana use may induce lethargy (Delisle et al. 2010; Irons et al. 2014; Pesta et al. 2013). However, Sabia et al. (Forthcoming) also find evidence that MMLs are associated with improved physical mobility for older individuals, consistent with pain-alleviating effects of marijuana consumption for medicinal purposes. This suggests that MMLs may increase the probability of employment for older individuals.

There is also evidence that MMLs may affect the demand for substitutes and complements of marijuana. Using data from the Behavioral Risk Factor Surveillance System (BRFSS) from 1990 to the early 2010s, Anderson et al. (2013) and Sabia et al. (Forthcoming) find evidence that MMLs are associated with a decline in alcohol consumption, suggesting that alcohol and marijuana are substitutes. However, Wen et al. (2014) and Choi (2014) use data from the NSDUH from 2004 to 2012 and find that the enforcement of MMLs is associated with increases in alcohol consumption. These contradictory findings could suggest some policy heterogeneity, a result also supported by Pacula et al. (2013).

The alcohol effects of MML-induced increases in marijuana use could affect labor market outcomes, though a priori it is unclear in which direction. Using state beer taxes and per capita ethanol sales as instruments, Terza (2002) finds evidence of a negative relationship between problem drinking and employment. However, Feng et al. (2001) find that counties that become "wet"- that is, liberalizing alcohol sales regulations_-see increases in male employment. Moreover, Auld (2005) finds evidence that moderate drinking is positively related to males' 
wages, even after controlling for the endogeneity of alcohol consumption. This finding appears to exist for females as well, where the relationship between alcohol consumption and earnings may be even stronger (see, for example, Berger and Leigh 1988; MacDonald and Shields 2001; Mullahy and Sindelar 1991; Peters 2004; Peters and Stringham 2006; and Tekin 2004). These findings could suggest a beneficial "social lubricating" effect of alcohol consumption that aids labor market networking.

In addition, MMLs could also affect labor market outcomes if they induce consumption of harder drugs, perhaps because marijuana acts as a "gateway" drug. However, work by Wen et al. (2014) and Choi (2014) find little evidence that MMLs are associated with changes in cocaine or other hard drug use.

Finally, MMLs could affect individuals' psychological health, which, in turn could affect labor market outcomes (see, for example, Fletcher 2013). Anderson et al. (2013) find that MMLs are associated with a reduction in suicide rates, which could suggest mental health benefits of increased marijuana use. On the other hand, Sabia et al. (Forthcoming) find little evidence that MMLs affect days of poor mental health. ${ }^{4}$

Contributions. The current study is the first in the literature to examine the effects of medical marijuana laws on labor market outcomes. We also explore heterogeneity in the labor market effects of MMLs by gender and age, which may be important given gender- and agespecific variation in medicinal versus recreational use of marijuana (Doyle and Sheasley 2012; Sabia et al. Forthcoming). In addition, given that there is substantial heterogeneity in state MMLs, we also explore whether the labor market effects of MMLs differ by the type of law.

\footnotetext{
${ }^{4}$ Rylander et al. (2014) also find no evidence of a statistically significant association between the number of marijuana registrants and completed suicides.
} 
Finally, we provide some descriptive evidence on mechanisms that could be at work to explain a link between MMLs and labor market outcomes.

\section{Data and Measures}

The analysis uses repeated cross-sections of the Current Population Survey (CPS) Outgoing Rotation Groups from January 1990 to December 2014, available from the Bureau of Labor Statistics. When weighted using CPS sampling weights, these data are representative of the U.S. population. These data are useful for this study because they contain information on key labor market outcomes of interest, including employment, hours worked, and hourly earnings. The analysis focuses on the working age population ages 18-to-64; we separate our analysis for males and females.

Dependent Variables. We measure labor supply on both the extensive and intensive margins. First, Employment is a dichotomous indicator set equal to one if the respondent reports positive hours of paid employment. As shown in Table 1A, 65.2 percent of 18-to-64 year-old men and 58.3 percent of women reported employment.

We measure labor supply on the intensive margin by measuring usual weekly hours of work at the worker's main job, conditional on employment. Among men, the average weekly hours of work was 41.5 hours, while for women it was 36.8 hours. We experimented with use of current hours of work as an alternative measure of labor supply at the intensive margin. This measure produced results similar to those reported below.

Finally, we measure labor market productivity using the respondent's hourly earnings. For workers who report being paid hourly, his or her hourly wage rate is directly reported. For those who are not paid hourly, the wage rate is calculated as the ratio of usual weekly earnings to 
usual weekly hours. The average wage rate (in 2014 dollars) earned by males was $\$ 22.94$ per hour and by females was $\$ 18.65$ per hour.

Medical Marijuana Laws. Our primary analysis uses effective dates agreed upon by Anderson et al. (2013), Wen et al. (2014), and Sabia et al. (Forthcoming) and updated using our own study of legislative statutes and ballot initiatives, confirmed using ProCon.org. These effective dates are shown in Table 2. During the 1990 to 2013 period, 23 states and the District of Columbia enacted MMLs. There are, however, some minor differences in preferred effective dates (see Powell et al. (2015), though they generally only differ by a matter of months. ${ }^{5}$ Thus, we also experiment with an alternate coding of MMLs using Powell et al. (2015). ${ }^{6}$

There is substantial heterogeneity in state MMLs, as discussed extensively by Anderson et al. (2013), Pacula et al. (2013), and Sabia et al. (Forthcoming). For instance, some MMLs legalize collective cultivation of marijuana for multiple patients. Anderson et al. (2013) argue that collective cultivation provisions may be an important driver of supply-side declines in the street price of marijuana in the recreational market. In Appendix Table 3, we provide details regarding the provisions of each state's MML. In our analysis below, we also explore heterogeneity in the effect of MMLs by the provision of MMLs that allow (i) collective cultivation of medical marijuana (9 states), (ii) home cultivation of medical marijuana (14

\footnotetext{
${ }^{5}$ One exception is Maryland, which Powell et al. (2015) code as having enforced an MML beginning in 2003. In contrast, neither Wen et al. (2014) nor Anderson et al. (2013) code Maryland in this matter. The difference appears to be driven by authors' differences in interpretation of an MML. In 2003, Maryland adopted a law that allowed defendants prosecuted for marijuana possession to claim, as a mitigating circumstance, their possession of marijuana was for medical purposes. This law, however, did not prevent patients from getting arrested, prosecuted or fined. In 2013, the state passed another law to allow the distribution of medical marijuana through academic centers, none of which accepted the appointment. The current MML which took effect on June 1, 2014 was the first to set regulations on dispensaries, patient registries, fees, possession limits, qualifying conditions and more. We experiment with an alternate coding of Maryland's law, but find a qualitatively similar pattern of results.

${ }^{6}$ We also experiment with alternative coding of the MML law to render small month-specific differences in agreedupon effective dates generally moot: (i) MML set equal to lif a state had an effective MML law in the entire year and 0 otherwise, and (ii) MML set equal to 1 if a state had an effective MML law at any time in a year and 0 otherwise. The findings from these specifications are qualitatively and quantitatively similar (see Appendix Tables 1 and 2).
} 
states), and (iii) medical marijuana to be prescribed for pain (16 states). By the end of 2014, eight states, including Arizona, California, Colorado, Montana, Nevada, Oregon and Rhode Island, had implemented all three of the above provisions.

\section{Empirical Strategy}

We begin by pooling repeated cross-sections of states and months between January 1990 and December 2014 and estimating a difference-in-difference model of the following form:

$$
E_{\text {ismt }}=\beta_{0}+\beta_{1} M_{M} L_{s m t}+X^{\prime}{ }_{s t} \beta_{2}+Z^{\prime}{ }_{\text {imt }} \beta_{3}+v_{s}+\kappa_{m}+\omega_{t}+\varepsilon \text { imst }
$$

where Eist measures the labor market outcome (employment, usual hours worked, or hourly wages) of individual $i$ residing in state $s$ at time t, MML is an indicator for whether state $s$ had an MML law in effect in month $m$ in year $t, \mathbf{X}_{\text {st }}$ is a vector of time-varying state controls, $\mathbf{Z}_{\mathrm{imt}}$ is a vector of individual-level time-varying controls, $\mathrm{v}_{\mathrm{s}}$ is a time-invariant state effect, $\kappa_{\mathrm{m}}$ is a month effect, and $\omega_{\mathrm{t}}$ is a state-invariant time effect. Included in vector $\mathbf{X}_{\text {st }}$ are the real value of the higher of the state or federal minimum wage, real per-pack cigarette and beer taxes, an indicator for whether a state has decriminalized marijuana, and real state GDP per working-age (18-64) person. ${ }^{7}$ Included in the vector of individual-level controls $\mathbf{Z}_{\text {ist }}$ for the employment regressions are age (linear and squared), years of school completed, marital status, and race/ethnicity and whether the respondent is enrolled in school. In the conditional hours and wage regressions, we also include potential experience (age minus years of schooling completed minus 6) and

\footnotetext{
${ }^{7}$ We include state per capita GDP to control for state business cycle effects, but it is also a measure of income that could be affected by MMLs. Results are qualitatively and quantitatively similar to when omitting state per capita GDP as a control.
} 
dummies for the worker's main industry. The means of each of our control variables appear in Table 1B.

The key parameter of interest, $\beta_{1}$, captures the relationship between MMLs and labor market outcomes. Identification of this parameter comes from the states that began enforcing MMLs between January 1990 and December 2014. The credibility of the identification of $\beta_{1}$ depends on the common trends assumption of our difference-in-difference model. This assumption could be violated if (i) there are state-level time-varying unobservables — such as anti-marijuana legalization sentiment - that are correlated with both the adoption of MMLs and with drug use, which could affect labor market outcomes, (ii) trends in labor market outcomes differ in MML states relative to comparison states prior to the adoption of an MML, or (iii) MMLs are adopted in response to labor market trends.

We use a number of econometric strategies to address the possibility that the common trends assumption might be violated. First, as noted above, we include controls for state-specific policies related to risky health behaviors (beer taxes, cigarette taxes, marijuana decriminalization laws), the state business cycle (state per capita GDP), and demographic trends (age, potential experience, race, marital status, and school enrollment). Second, we add state-specific linear time trends to the right hand-side of equation (1) to control for any unmeasured time trends that are unfolding linearly. Third, we draw data from the General Social Survey (GSS) to explicitly control for state-level anti-marijuana legalization sentiment. Respondents to the GSS were asked:

"Do you think the use of marijuana should be made legal or not?” 
In 1990, 83.2 percent of all GSS respondents reported opposition to the legalization of marijuana; this figure fell to 51.6 percent by $2010 .^{8}$ An examination of our estimate of $\beta_{1}$ from equation (1) including this control will allow us to separate the effects of medical marijuana legalization from endogenous state sentiment changes. Fourth, we examine four years of MML policy leads to test for differential state trends occurring prior to the implementation of an MML in treatment and control states.

Finally, we pursue a synthetic control design approach following Abadie et al. (2010), which involves the construction of data-driven counterfactuals for each MML state. The donor states are comprised of those 27 states that did not implement an MML between January 1, 1990 and December 31, 2014. The synthetic state for each MML state is generated using pre-treatment levels and trends in each of our controls (years of school completed, marital status, and race/ethnicity, school enrollment status, industry of main job, effective state minimum wage, state real per-pack cigarette and beer taxes, the presence of a state decriminalized marijuana law, real state GDP per person ages 18-to-64), and the natural logs of real hourly wages in years prior to the adoption of an MML. Each synthetic state is comprised of a weighted linear combination of the donor states. We then estimate a difference-in-difference estimates using the treatment state and its positively weighted donor states, and weight regressions using synthetic weights.

Statistical inference from synthetic estimates is made in two ways: (i) using wild bootstrapped standard errors clustered on the state, a procedure commonly used with small numbers of clusters (Cameron et al. 2008), and (ii) generating p-values for our synthetic estimates using a permutation-type test whereby we assign a placebo MML effective dates (equivalent to the treatment state's actual effective date) to each donor state to simulate the

\footnotetext{
${ }^{8}$ One limitation of this measure is that it is only available for the calendar years 1990-1991, 1993, and evennumbered years between 1994 and 2000. In those years, the data are non-missing in 79 percent of state-year cells. Anti-marijuana legalization sentiment is not measured in Nevada or Nebraska in the GSS.
} 
distribution of estimates under the null hypothesis (that there is no effect) and then calculate a pvalue for the "true" estimate (Adabie et al. 2010).

\section{Main Results}

The findings appear in Tables 3 through 10. For ease of presentation, we present estimates of $\beta_{1}$ in our tables, but estimated coefficients on the controls are available upon request. We present estimates separately by gender and age to allow for heterogeneity in policy impacts. All difference-in-difference regressions are weighted by the CPS sample weights, and standard errors corrected for clustering on the state. As noted above, synthetic regressions are weighted by the synthetic control weights. Wild bootstrapped standard errors and placebo p-values calculated as described above are reported.

In Table 3, we present the estimates of the effect of MMLs on employment. Baseline difference-in-difference estimates (Panel I) show little evidence that MMLs are associated with economically or statistically significant changes in labor supply at the extensive margin for the pooled, male, or female samples. These estimates become smaller and remain indistinguishable from zero after controlling for state-specific linear time trends (Panel II). When controlling for state-specific linear time trends (Panel II), the precision of our estimates is such that we can rule out, with 95 percent confidence, employment reductions greater than 2.7 percent for males and 3.9 percent for females. We can also rule out employment gains greater than 6.5 percent for males and 4.4 percent for females. ${ }^{9}$

Table 4 presents the estimates of the relationship between MMLs and the natural log of hours worked among employed individuals. We find little evidence in Panels I and II that the

\footnotetext{
${ }^{9}$ In Appendix Table 4, we experiment with our employment definition to include self-employment, which could be important for the secondary marijuana market. The pattern of results suggests little consistent evidence that MMLs affect employment using this broader employment definition, with the possible exception of older males.
} 
enforcement of MMLs is associated with economically or statistically significant impacts on labor supply at the intensive margin. In models that include state-specific time trends (Panel II), the precision of our estimates is such that we can rule out, with 95 percent confidence, MMLinduced hours reductions greater than 1.8 percent for males and 2.5 percent for females. We can also rule out MML-induced hours gains greater than 4.9 percent for males and 6.3 percent for females. Together, our estimates in Tables 3 and 4 provide little evidence that state MMLs is associated with economically or statistically significant changes in labor supply on either the extensive or intensive margins for males or females.

Wages. In Table 5, we turn to the effect of MMLs on wages. While we find that the enforcement of an MML is associated with little change in wages for teenage males-a population for whom there is relatively little evidence of MML-induced marijuana spilloversthere is some evidence that MMLs are negatively related with hourly earnings of young adult males, particularly those ages 20 to 39 , a population whose marijuana use has been shown to rise in response to MMLs. Specifically, for young males ages 20-to-29 (Panel I, column 3), enforcement of an MML is associated with a 2.5 percent decrease in hourly wages, and for those ages 30-to-39 (Panel I, column 4), a (statistically insignificant) 1.3 percent decline in wages. The inclusion of state-specific linear time trends as controls (Panel II) produces a similar pattern of results. Our estimates suggest little evidence that the enforcement of MMLs is associated with changes in wages for women, though the estimates are generally negative for those over age 20 . When we estimate a wage equation that corrects for selection into employment via a Heckman selection correction technique, the results follow a similar pattern (Appendix Table 5). In addition, when we use effective date coding preferred by Powell et al. (2015), the pattern of results is also similar (see Appendix 6). 
The credibility of our estimates of $\beta_{1}$ relies on the parallel trends assumption of our difference-in-difference approach. One threat to the validity of our research design would be if a state MML is simply serving as a proxy for state-specific time-varying changes in marijuana legalization sentiment. Using our measure of anti-marijuana sentiment obtained from the GSS as an additional explanatory variable, we re-estimate equation (1), including state linear time trends, for each of our outcomes. The estimates, presented in Table 6 , show a pattern of results similar to our findings in Tables 3 through $5 .{ }^{10}$

\section{Sensitivity of Wage Results to Alternate Specifications}

Could the negative wage effects of MMLs we obtain, particularly for young males, be contaminated by the differential pre-treatment trends in labor market outcomes in MML and non-MML states? And could the effects of MMLs take time to unfold? To address these possibilities, in Table 7, we add controls for four years of MML policy leads and three years of policy lags. The results, in general, provide little support for significant effects of policy leads, either when individually or jointly considered. After controlling for policy leads, however, we continue to find that the enforcement of an MML is associated with a significant decline in hourly wages for younger males, particularly those under 40 and especially for those ages 20-to29. Moreover, the effects appear to get larger over time, reaching 3 to 5 percent, suggesting possible cumulative negative effects of MMLs on productivity. ${ }^{11}$

\footnotetext{
${ }^{10}$ As noted earlier, the sample sizes in the regressions controlling for anti-marijuana sentiment are smaller than those in our baseline regressions, for anti-marijuana legalization sentiment is not measured in Nevada or Nebraska in the GSS.

${ }^{11}$ See Appendix Tables 7 and 8 for the long-run effect of state MML on employment and log hours.
} 
While the lack of evidence for differential pre-treatment trends in wages for MML and non-MML states gives us some confidence that our estimates are capturing policy impacts, we next examine whether the effects we observe for younger adults persist when we use a synthetic control design. We focus on younger males ages 20-to-29, the population for whom the largest negative wage effects are observed. As noted above, each treatment state's synthetic control is a weighted linear combination of the control states. For instance, the synthetic counterfactual for Montana is comprised of 29.1 percent North Dakota, 29.4 percent South Dakota, 21.4 percent Arkansas, 9.3 percent Kentucky, and 10.8 percent Wyoming while the synthetic counterfactual for New York is comprised of 79.1 percent Virginia, and 20.9 percent Pennsylvania. The synthetic control weights for each treatment state are shown in Appendix Table 9.

Figures 1 through 4 show trends in wages for males 20-to-29 for each of the MML states and their synthetic control state. The vertical line denotes the year a given state's MML is enforced. Prior to the implementation of MMLs, the trends in hourly wages are similar in many treatment and their counterfactual synthetic states, such as Arizona, California, Montana, Nevada, New Mexico, Oregon and Vermont, as measured using the root mean square prediction error (RMSPE) between the MML state and the synthetic control state in the pre-treatment period $(<0.035)$. For some states, however — particularly smaller states with more volatile pretreatment wage trends due to smaller samples - the pre-treatment wage trends match less well (see, for example, Connecticut and the District of Columbia).

In Table 8, we present our synthetic difference-in-difference estimates. Though the point estimates continue to suggest negative wage effects of MMLs for young men, generating our standard errors via clustered wild bootstrapping or our p-values via permutation-type placebotests renders many of these estimates statistically indistinguishable from zero. Thus, we view 
our synthetic estimates as suggestive rather than dispositive of negative wage effects for young men.

Mechanisms. If MMLs are associated with a reduction in earnings for young men, what could explain such an effect? While we do not have data on individuals' cognitive processes across states and over time, we attempt to measure two other potential channels identified in the literature: alcohol consumption and lethargy. For this purpose, we draw data from the Behavioral Risk Factor Surveillance System (BRFSS) from 1990 to 2013. We measure alcohol consumption as the number of alcoholic beverages the respondent has consumed per month, a standard measure used in the medical marijuana literature (Anderson et al. 2013; Sabia et al. Forthcoming). ${ }^{12}$ Our measure of lethargy is imperfect, as it is actually a measure of exercise. Respondents to the BRFSS are asked about the number of days they engage in vigorous activities in a usual week. ${ }^{13}$ While this measure may be correlated with lethargy, it may also capture one's physical mobility, which could itself be affected by MMLs. For example, if marijuana is used for medicinal purposes to ameliorate pain associated with joint ailments, arthritic problems, or fibromyalgia, then MMLs could increase physical mobility (see Sabia et al. Forthcoming).

The results - estimated via negative binomial for exercise days and least squares for alcoholic beverages - provide some evidence that these mechanisms may be important in understanding the labor market consequences of MMLs. We find that the enforcement of MMLs is associated with a reduction in exercise days (Panel I) and alcohol consumption (Panel II)

\footnotetext{
12 The average number of drinks in the previous month is calculated using the respondent' responses to the following questions, "Have you had any beer, wine, wine coolers, cocktails, or liquor during the past month?", "During the past month, how many days per week or per month did you drink any alcoholic beverages, on the average?" and "On days when you drink, about how many drinks do you drink on average?"

${ }^{13}$ Vigorous exercise is measured as the number of days the respondent engaged in vigorous activities in a usual week. The measure is generated using the questionnaire item: "How many days per week do you do vigorous activities such as running, aerobics, heavy yard work, or anything else that causes large increases in breathing or heart rate for at least 10 minutes at a time?"
} 
among younger adults. These results are consistent with spillover effects of medical marijuana into the youth recreational market that could suggest (i) lethargy-inducing effects of marijuana use, and (ii) a substitution away from alcohol, a "social lubricant" that may be important for labor market networking. However, these effects are also observed across age groups other than simply young males. For example, we find that the implementation of MMLs is associated with a 12.75 percent decrease in alcohol consumption for females ages 20 -to-29 and a 5.4 percent decrease in alcohol consumption for females ages 50-to-64. These estimates are inconsistent with previous studies finding the positive relationship between alcohol consumption and earnings may be stronger for women than men (Berger and Leigh 1988; MacDonald and Shields 2001; Mullahy and Sindelar 1991; Peters 2004; Peters and Stringham 2006; and Tekin 2004). Thus, it is probably not the case that alcohol consumption or lethargy-inducing effects of marijuana can fully explain the effect we observe. Rather, effects on cognitive functioning, job tenure or occupational mobility may also be important. Unfortunately, such measures are not included along with earnings information in the CPS outgoing rotation groups.

Heterogeneity in MMLs. Finally, we explore heterogeneity in the wage effects of MMLs by type of MML. As a number of scholars have documented, MMLs across different states have different components which affect marijuana users' incentives and behaviors differently (Anderson et al. 2013; Pacula 2013). In Table 10, we explore the wage effects of different components of MMLs, including provisions that allow for (i) collective cultivation of medical marijuana for multiple patients, (ii) home cultivation of medical marijuana, and (iii) prescriptions for chronic pain. The results suggest that the largest adverse wage effects may be driven by state MMLs that allow collective cultivation for multiple patients. This finding is consistent with the 
hypothesis that these provisions are an important driver of supply-side price reductions in recreational marijuana (Anderson et al. 2013; Sabia et al. Forthcoming).

\section{Conclusions}

Recent research by Wen et al. (2014) and Anderson and Rees (2011) suggest that MMLs are associated with increases in marijuana use among adults. However, to our knowledge, no research has been conducted on the labor market consequences of these laws. This study presents the first estimates of the relationship between state medical marijuana laws and labor market outcomes. Difference-in-difference estimates suggest that the enforcement of a state MML is associated with a 2 to 3 percent reduction in hourly earnings of young men ages 20 -to29. These results are generally robust to the inclusion of controls for state-level time-varying substance use policies, state-specific linear time trends, and state-specific anti-marijuana legalization sentiment. However, they are somewhat weaker and less precisely estimated with the use of a synthetic cohort design.

The wage effects we obtain for younger males appear to be largely driven by state MMLs with provisions allowing collective cultivation for multiple patients. Descriptive evidence suggests that lethargy-inducing effects of marijuana and a substitution away from alcohol—a "social lubricant" that may be important for labor market networking — may be channels at work to explain this relationship. However, given that MMLs also appear to affect exercise and drinking among some older individuals, these mechanisms cannot explain the entire story. Future research is necessary to better understand the channels at work.

There are a number of limitations of this study worthy of note. This study uses a reduced form approach rather than a structural model. Because the CPS Outgoing Rotation Groups do 
not include information on marijuana consumption, our approach does not immediately yield estimates of the wage effect of MMLs on individuals who are induced to use marijuana because of MMLs, i.e. the average treatment effect on the treated (ATET). Rather, the wage effects we obtain should be interpreted as “intent to treat" (ITT) estimates. Using Wen et al.'s (2014) estimates that find MMLs increase marijuana consumption by 16 percent on the extensive margin and 17 percent on the intensive margin among individuals over age 21 , we obtain implied bounds for ATETs indicating a 14.7 to 16.9 percent decline in wages of affected young adults. Second, our data are limited in allowing us to explore all of the mechanisms through which MMLs may affect labor market outcomes - particularly cognition. Future work examining the labor market effects of medical marijuana laws as well as broader marijuana legalization laws such as those adopted recently in Colorado and Washington, will benefit from further exploiting of channels through which MMLs affect labor market outcomes. 


\section{References}

Abadie, Alberto, Alexis Diamond, and Jens Hainmueller. "Synthetic control methods for comparative case studies: Estimating the effect of California's tobacco control program." Journal of the American Statistical Association 105.490 (2010).

Anderson, D. Mark, and Daniel I. Rees. 2011. "Medical marijuana laws, traffic fatalities, and alcohol consumption." IZA working paper no 6112. Available at: http://ftp.iza.org/dp6112.pdf

Anderson, D. Mark, Benjamin Hansen, and Daniel I. Rees. 2013. "Medical marijuana laws, traffic fatalities, and alcohol consumption." Journal of Law and Economics 56(2):333-369.

Anderson, D. Mark, Benjamin Hansen, and Daniel I. Rees. 2015. " Medical Marijuana Laws and Teen Marijuana Use." The American Law and Economics Review doi 10.1093/aler/ahv002.

Anderson, D. Mark, and Daniel I. Rees. 2014. "The Legalization of Recreational Marijuana: How Likely Is the Worst-Case Scenario?" Journal of Policy Analysis and Management 33: 221232. doi: 10.1002/pam.21727

Anderson, D. M., Rees, D. I., and Sabia, J. J. 2014. "Medical marijuana laws and suicides by gender and age." American Journal of Public Health, 104(12): 2369-2376.

Ashenfelter, Orley and Krueger, Alan B, 1994."Estimates of the Economic Returns to Schooling from a New Sample of Twins," American Economic Review, 84(5):1157-73.

Auld, M. Christopher. 2005. "Smoking, drinking, and income." The Journal of Human Resources 15:504-518.

Banerjee, Souvik, Pinka Chatterji and Kajal Lahiri. 2013. "Effects of Psychiatric Disorders on Labor Market Outcomes: A Latent Variable Approach Using Multiple clinical Indicators." CESifo Working Paper Series 4260, CESifo Group Munich.

Berger, M. C., and Leigh, J. P. 1988. "The effect of alcohol use on wages." Applied Economics 20(2): 1343-1351.

Blake, D.R., Robson, P., Ho, M., Jubb, R.W., McCabe, C.S., 2005. "Preliminary assessment of the efficacy, tolerability and safety of a cannabis-based medicine (Sativex) in the treatment of pain caused by rheumatoid arthritis." Rheumatology (advance access published November 9 , 2005).

Buchmueller, Thomas C. and Samuel H. Zuvekas, 1998. "Drug use, drug abuse, and labour market outcomes," Health Economics, 7(3): 229-245.

Cameron, Colin, Jonah Gelbach and Douglas Miller. 2008. "Bootstrap-Based Improvements for Inference with Clustered Errors." Review of Economics and Statistics 90: 414-427. 
Cawley, John, and Christopher J. Ruhm. 2012. "The Economics of Risky Health Behaviors." Chapter 3 in: Thomas G. McGuire, Mark V. Pauly, and Pedro Pita Barros (editors), Handbook of Health Economics 2: 95-199.

Chatterji, Pinka. 2003. "Illicit Drug Use and Educational Attainment," NBER Working Papers 10045, National Bureau of Economic Research, Inc.

Chatterji, Pinka and Jeffrey DeSimone, 2006. "High School Alcohol Use and Young Adult Labor Market Outcomes," NBER Working Papers 12529, National Bureau of Economic Research, Inc.

Chen, Chuan-Yu and Keh-Ming Lin. 2009. "Health Consequences of Illegal Drug Use," Current Opinion in Psychiatry 22(3):287-292.

Choi, Ana. 2014. "The impact of medical marijuana laws on marijuana use and other risky health behaviors." PhD dissertation, Cornell University.

Conti, G. 2010. “Cognition, cannabis and wages.” IZA working paper. Available at:

http://www.iza.org/conference_files/riskonomics2010/conti_g5865.pdf

Crost, B., and Guerrero, S. 2012. "The Effect of Alcohol Availability on Marijuana Use:

Evidence from the Minimum Legal Drinking Age." Journal of Health Economics 31(1): 112-

121. doi:http://dx.doi.org.libproxy.sdsu.edu/10.1016/j.jhealeco.2011.12.005

Delisle, T. T., Werch, C. E., Wong, A. H., Bian, H., and Weiler, R. 2010. "Relationship between frequency and intensity of physical activity and health behaviors of adolescents." Journal of School Health, 80(3): 134-140.

Degenhardt, L., Hall, W., and Lynskey, M. 2003.” Exploring the association between cannabis use and depression." Addiction, 98(11): 1493-1504.

DeSimone, Jeff. "Illegal drug use and employment." Journal of Labor Economics 20.4 (2002): 952-977.

Deza, Monica. 2012. "Essays on Drug Use and Crime." UC Berkeley: Economics. Retrieved from: http://www.escholarship.org/uc/item/37c2v560

Doblin, R. E., and Kleiman, M. A. 1991. "Marijuana as antiemetic medicine: a survey of oncologists' experiences and attitudes." Journal of Clinical Oncology, 9(7): 1314-1319.

Doyle, Katie and Sheasley, Chelsea. "Older Males Top Use in Other States." The Boston University Statehouse Program. Boston University: College of Communication. December 2012. http://www.bu.edu/statehouse/2012/12/22/older-males-top-use-in-other-states/ 
Ettner, Susan L., Richard G. Frank and Ronald C. Kessler, 1997. "The Impact of Psychiatric Disorders on Labor Market Outcomes,"NBER Working Papers 5989, National Bureau of Economic Research, Inc.

Feng, W., W. Zhou, J. Beutler, B. Booth, and M. French. 2001. "The Impact of Problem Drinking on Employment. Health Economics 10(6): 509-21.

Fiz J, Duran M, Capella D, Carbonell J, Farre M. 2011. "Cannabis use in patients with fibromyalgia: effect on symptoms relief and health-related quality of life." PLOS ONE 6:e18440.

Fletcher, Jason. 2013."Adolescent Depression and Adult Labor Market Outcomes," Southern Economic Journal 80(1):26-49.

French, Michael T., and Gary A. Zarkin. 1995. "Is moderate alcohol use related to wages? Evidence from four worksites." Journal of health economics 14(3): 319-344.

French, Michael T., M. Christopher Roebuck, and Pierre Kebreau Alexandre. 2001. "Illicit drug use, employment, and labor force participation." Southern Economic Journal 68(2): 349-368.

Frijters, Paul, Johnston, David W. and Shields, Michael A. 2010. "Mental Health and Labour Market Participation: Evidence from IV Panel Data Models," IZA Discussion Papers 4883, Institute for the Study of Labor (IZA).

Galuppo, M., Giacoppo, S., Bramanti, P., and Mazzon, E. 2014. "Use of Natural Compounds in the Management of Diabetic Peripheral Neuropathy." Molecules, 19(3): 2877-2895.

Gill, Andrew M., and Robert J. Michaels. 1992. "Does drug use lower wages?" Industrial and Labor Relations Review, 45: 435-448.

Green, B. E. and Ritter, C. 2000. "Marijuana use and depression." Journal of Health and Social Behavior, 40-49.

Hall, W. 2009. "The adverse health effects of cannabis use: What are they, and what are their implications for policy?" International Journal of drug policy 20(6): 458-466.

Hall, W., Christie, M., and Currow, D. 2005. "Cannabinoids and cancer: causation, remediation, and palliation." The lancet oncology, 6(1): 35-42.

Hanson, Karen L., Jennifer L. Winward, Alecia D. Schweinsburg, Krista Lisdahl Medina, Sandra A. Brown, Susan F. Tapert. 2010. "Longitudinal study of cognition among adolescent marijuana users over three weeks of abstinence." Addictive Behaviors, 35(11): 970-976

Harder, Valerie S. and Howard D. Chilcoat. 2007. "Cocaine use and educational achievement: understanding a changing association over the past 2 decades." American Journal of Public Health, 97(10):1790. 
Harder, V. S., Morral, A. R., and Arkes, J. 2006. "Marijuana use and depression among adults: Testing for causal associations." Addiction, 101: 1463-1472.

Irons, J. G., Babson, K. A., Bergeria, C. L., and Bonn-Miller, M. O. 2014. "Physical activity and cannabis cessation." The American Journal on Addictions 23(5): 485-492.

Kandel, Denise B. and Davies, Mark. 1990. "Labor Force Experiences of a National Sample of Young Adult Men: The Role of Drug Involvement." Youth and Society, 21(4): 411-445.

Lotan, I., Treves, T. A., Roditi, Y., and Djaldetti, R. 2014. "Cannabis (Medical Marijuana) Treatment for Motor and Non-Motor Symptoms of Parkinson Disease: An Open-Label Observational Study." Clinical neuropharmacology 37(2): 41-44.

MacDonald, Z., and Michael S. A. 2001. "The Impact of Alcohol Consumption on Occupational Attainment in England." Economica 68(271): 427-453.

MacDonald, Z., and Pudney, S. 2000. "Illicit Drug Use, Unemployment, and Occupational Attainment." Journal of Health Economics, 19(6): 1089-1115.

Macdonald, Scott; Kristin Anglin-Bodrug, Robert E. Mann, Patricia Erickson, Andrew Hathaway, Mary Chipman, Margaret Rylett. 2003. "Injury risk associated with cannabis and cocaine use." Drug and Alcohol Dependence 72(2): 99-115.

Malivert, Roland, and Joshua C. Hall. 2013. "The Effect of Medical Marijuana Laws on Extralegal Marijuana Prices." Atlantic Economic Journal 41(4): 455-456.

Marcel O. Bonn-Miller, Michael J. Zvolensky, Amit Bernstein. 2007. "Marijuana use motives: Concurrent relations to frequency of past 30-day use and anxiety sensitivity among young adult marijuana smokers." Addictive Behaviors, 32(1): 49-62.

Mills, C. J., and Noyes, H. L. 1984. "Patterns and correlates of initial and subsequent drug use among adolescents." Journal of Consulting and Clinical Psychology 52:231-243.

Miron, Jeffrey. 2005. "The budgetary implications of marijuana prohibition." Marijuana Policy Project.

Mullahy, J., and Sindelar, J. L. 1991. "Gender differences in labor market effects of alcoholism." American Economic Review 81(2): 161-165.

Naftali, T., Bar-Lev Schleider, L., Dotan, I., Lansky, E. P., Sklerovsky Benjaminov, F., and Konikoff, F. M. 2013. "Cannabis induces a clinical response in patients with Crohn's disease: a prospective placebo-controlled study." Clinical Gastroenterology and Hepatology, 11(10): 12761280. 
National Conference of State Legislatures.2014. "State Medical Marijuana Laws.” N.p., n.d. Web. May 16, 2014. http://www.ncsl.org/research/health/state-medical-marijuana-laws.aspx

Pacula, R.L, Powell, D., Heaton, P., and Sevigny, E.L. 2013. "Assessing the Effects of Medical Marijuana Laws on Marijuana and Alcohol Use: the Devil Is in the Details." NBER Working Paper No. 19302.

Pacula, R. L., Williams, J., Chaloupka, F. J., and Wechsler, H. 2004. "Alcohol and marijuana use among college students: economic complements or substitutes?" Health Economics, 13: 825843.

Parker, Linda A., Raphael Mechoulam, and Coralynne Schlievert. 2002. "Cannabidiol, a nonpsychoactive component of cannabis and its synthetic dimethylheptyl homolog suppress nausea in an experimental model with rats." Neuroreport 13(5): 567-570.

Pesta, D. H., Angadi, S. S., Burtscher, M., and Roberts, C. K. 2013. "The effects of caffeine, nicotine, ethanol, and tetrahydrocannabinol on exercise performance." Nutrition and Metabolism, 10(1): 71 .

Peters, Bethany. 2004. "Is there a wage bonus from drinking? Unobserved heterogeneity examined." Applied Economics, 36(20): 2299-2315.

Peters, Bethany. 2009."The drinkers' bonus in the military: officers versus enlisted personnel," Applied Economics, 41(17): 2211-2220.

Peters, Bethany L. and Edward Stringham, 2006. "No Booze? You May Lose: Why Drinkers Earn More Money Than Nondrinkers," Journal of Labor Research, 27(3): 411-421.

Powell, David, Rosalie Liccardo Pacula and Mireille Jacobson. 2015 "Does Medical Marijuana Laws Reduce Addictions and Deaths Related to Pain Killers? NBER Working Paper 21345. Available at: http://www.nber.org/papers/w21345

Quest Diagnostics. 2002. " Workplace Drug Use Decreased After September 11, 2001, According to Quest Diagnostics Drug Testing Index." Retrieved from http://www.questdiagnostics.com/dms/Documents/DTI-Reports/2002-06-28_DTI.pdf

Quest Diagnostics. 2014. "Workforce Drug Test Positivity Rate Increases for the First Time in 10 Years, Driven by Marijuana and Amphetamines, Finds Quest Diagnostics Drug Testing Index ${ }^{\mathrm{TM}}$ Analysis of Employment Drug Tests." Retrieved from http://www.questdiagnostics.com/home/physicians/health-trends/drug-testing

Register, Charles A., and Donald E. Williams. 1992."Labor market effects of marijuana and cocaine use among young men." Industrial and Labor Relations Review 45(3): 435-448. 
Riggs, P. K., Vaida, F., Rossi, S. S., Sorkin, L. S., Gouaux, B., Grant, I., et al. 2012. "A pilot study of the effects of cannabis on appetite hormones in HIV-infected adult men." Brain research 1431: 46-52.

Rylander, M., C. Valdez, and A.M. Nussbaum. 2014. "Does the legalization of medical marijuana increase completed suicide?” American Journal of Drug Alcohol Abuse 40(4): 269-73.

Sabia, Joseph J., Richard V. Burkhauser, and Benjamin Hansen. 2012. "Are the Effects of Minimum Wage Increases Always Small-New Evidence from a Case Study of New York State." Industrial and Labor Relations Review 65(2):350-376.

Sabia, Joseph J., Jeffrey Swigert, and Tim Young. Forthcoming. "The Effect of Medical Marijuana Laws on Body Weight," Health Economics.

Soria-Gómez, E., Bellocchio, L., Reguero, L., Lepousez, G., Martin, C., Bendahmane, M., et al. 2014. "The endocannabinoid system controls food intake via olfactory processes." Nature neuroscience 17(3): 407-415.

Substance Abuse and Mental Health Services Administration. 2014. "Results from the 2013 National Survey on Drug Use and Health: Summary of National Findings," NSDUH Series H48, HHS Publication No. (SMA) 14-4863. Rockville, MD: Substance Abuse and Mental Health Services Administration.

Tekin, E. 2004. "Employment, wages and alcohol consumption in Russia." Southern Economic Journal 71: 397-417.

Terza, Joseph V. 2002. "Alcohol Abuse and Employment: A Second Look.” Journal of Applied Econometrics 17(4): 393-404.

Van Ours, Jan C. 2006. "Cannabis, Cocaine and Jobs." Journal of Applied Econometrics 21(7): 897-917.

Van Ours, Jan C., and Jenny Williams. 2011. "Cannabis use and mental health problems." Journal of Applied Econometrics 26(7):1137-1156.

Van Ours, J. and Williams, J. 2014. "Cannabis Use and its Effects on Health, Education and Labor Market Success.” Journal of Economic Survey doi 10.1111/joes.12070.

Vinciguerra, V., T. Moore, and E. Brennan. 1988. "Inhalation Marijuana as an Antiemetic for Cancer Chemotherapy." New York State Journal of Medicine 88 (10): 525-7. http://www.ncbi.nlm.nih.gov/pubmed/3231372.

Vu, M. P., Melmed, G. Y., and Targan, S. R. 2013. "Weeding Out the Facts: The Reality About Cannabis and Crohn's Disease. Clinical gastroenterology and hepatology: the official clinical 
practice." Journal of the American Gastroenterological Association. DOI:

10.1016/j.cgh.2013.11.016

Washton, A.M., Gold, M.S., 1984. "Chronic cocaine abuse: evidence for adverse effects on health and functioning." Psychiatric Annals 14: 733 - 739.

Washton, Arnold M. and Andrew Tatarsky. 1983. “Adverse Effects of Cocaine Abuse.” National Institute on Drug Abuse Research Monograph Series 49. Available at http://ww1.drugabuse.gov/pdf/monographs/49.pdf\#page=260

Wen, Hefei, Jason M. Hockenberry, and Janet R. Cummings. 2014. "The Effect of Medical Marijuana Laws on Marijuana, Alcohol, and Hard Drug Use." Journal of Health Economics 42(3): 64-80.

Wozniak, Abigail K. 2012. "Discrimination and the Effects of Drug Testing on Black Employment." NBER Working Papers: 20095.

Zarkin, G. A., T. A. Mroz, J. W. Bray, and M. T. French 1998. "The relationship between drug use and labour supply for young men." Labour Economics 5(4):385-409. 
Figure 1. Trends in Log Hourly Wages in Northeastern MML States vs. Synthetic Control States for Males Ages 20-to-29
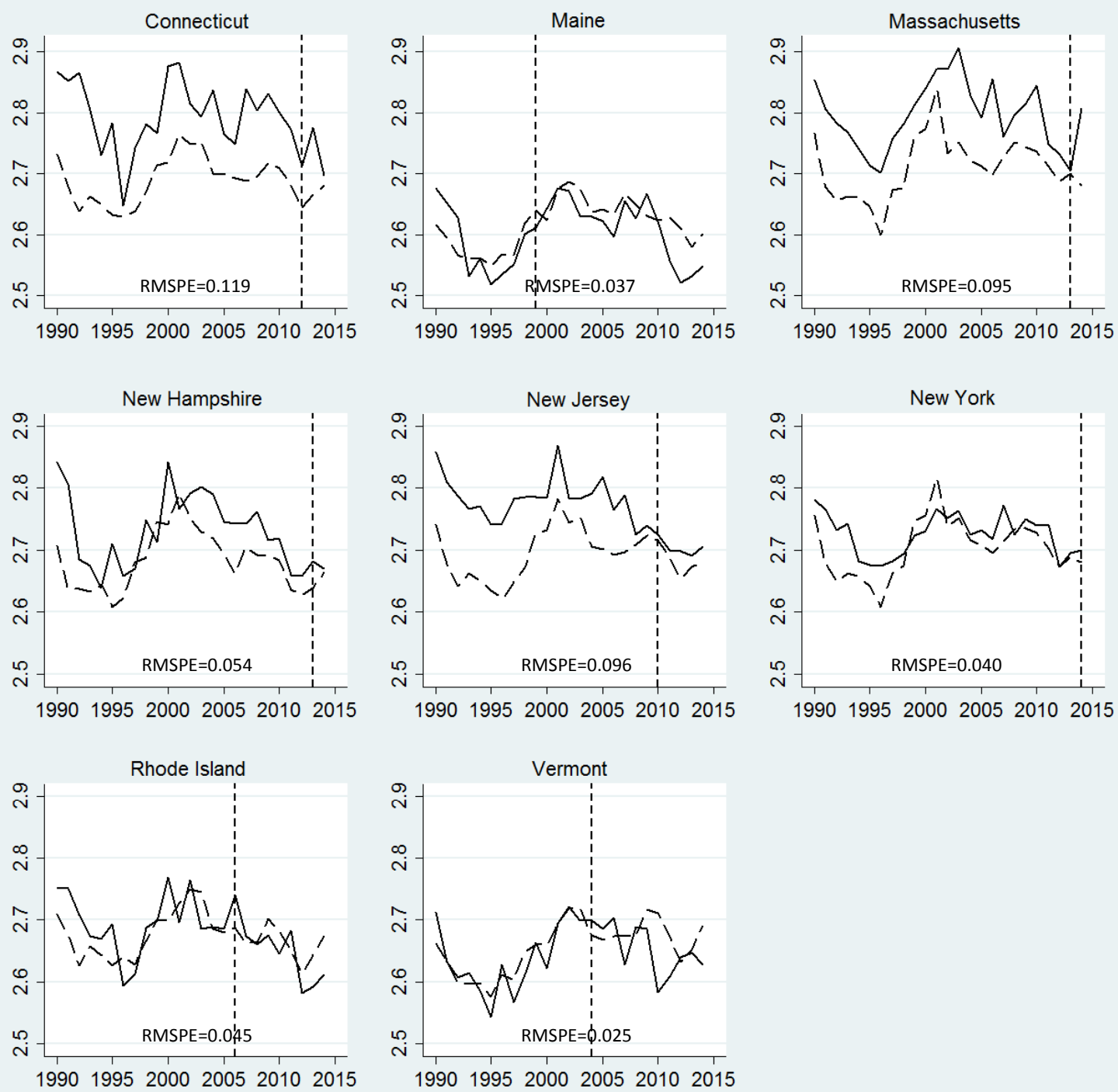

\section{MML state - - - - Synthetic control state}

Notes: Plots come from synthetic control analysis for each state, where the synthetic control state is a linear combination of donor states that did not implement MMLs from January 1, 1990 to December 31, 2014. The vertical line denotes the year a given state's MML is enforced. RMSPE indicates the root mean square prediction error between the MML state and the synthetic control state in the pre-treatment period. 
Figure 2. Trends in Log Hourly Wages in Western MML States vs. Synthetic Control States for Males Ages 20-to-29
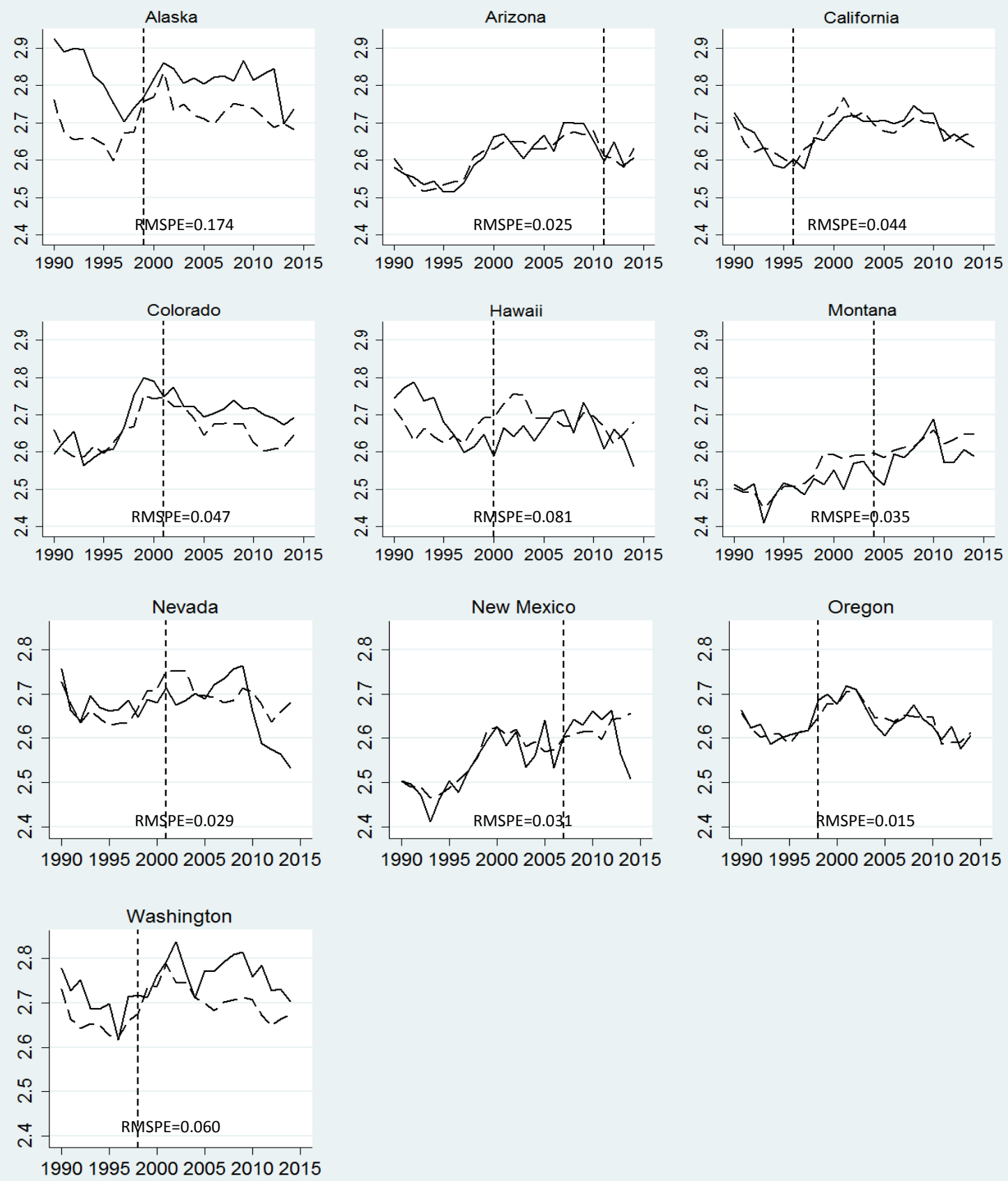

\section{MML state $\quad-----$ Synthetic control state}

Notes: Plots come from synthetic control analysis for each state, where the synthetic control state is a linear combination of donor states that did not implement MMLs from January 1, 1990 to December 31, 2014. The vertical line denotes the year a given state's MML is enforced. RMSPE indicates the root mean square prediction error between the MML state and the synthetic control state in the pre-treatment period. 
Figure 3. Trends in Log Hourly Wages in Mid-Western MML States vs. Synthetic Control States for Males Ages 20-to-29
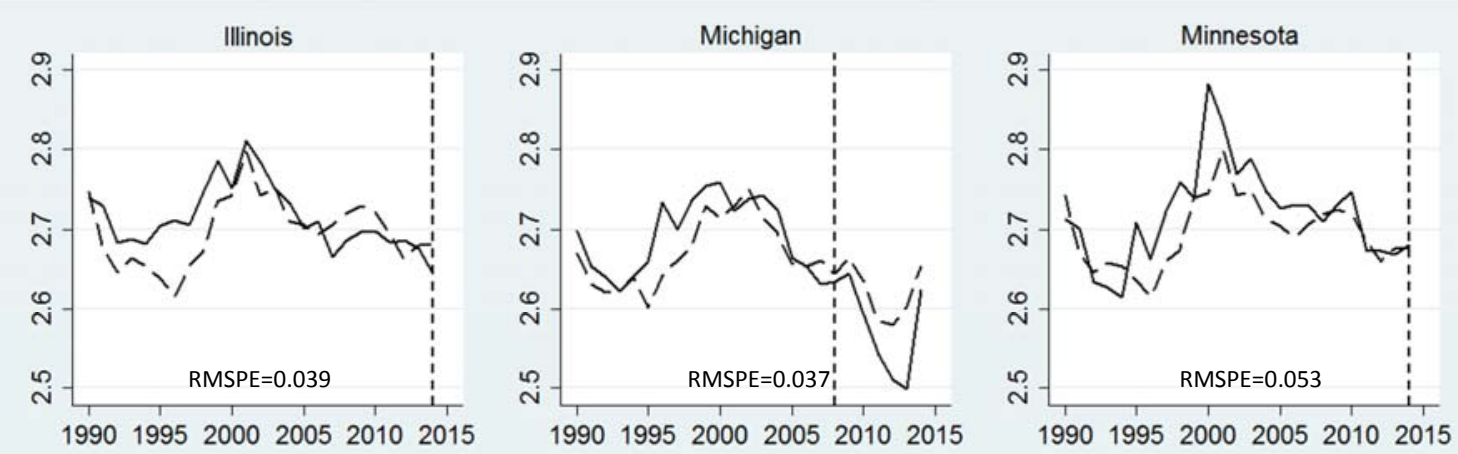

\section{MML state $\quad$ - - --- Synthetic control state}

Notes: Plots come from synthetic control analysis for each state, where the synthetic control state is a linear combination of donor states that did not implement MMLs from January 1, 1990 to December 31, 2014. The vertical line denotes the year a given state's MML is enforced. RMSPE indicates the root mean square prediction error between the MML state and the synthetic control state in the pre-treatment period.

Figure 4. Trends in Log Hourly Wages in Southern MML States vs. Synthetic Control States for Males Ages 20-to-29
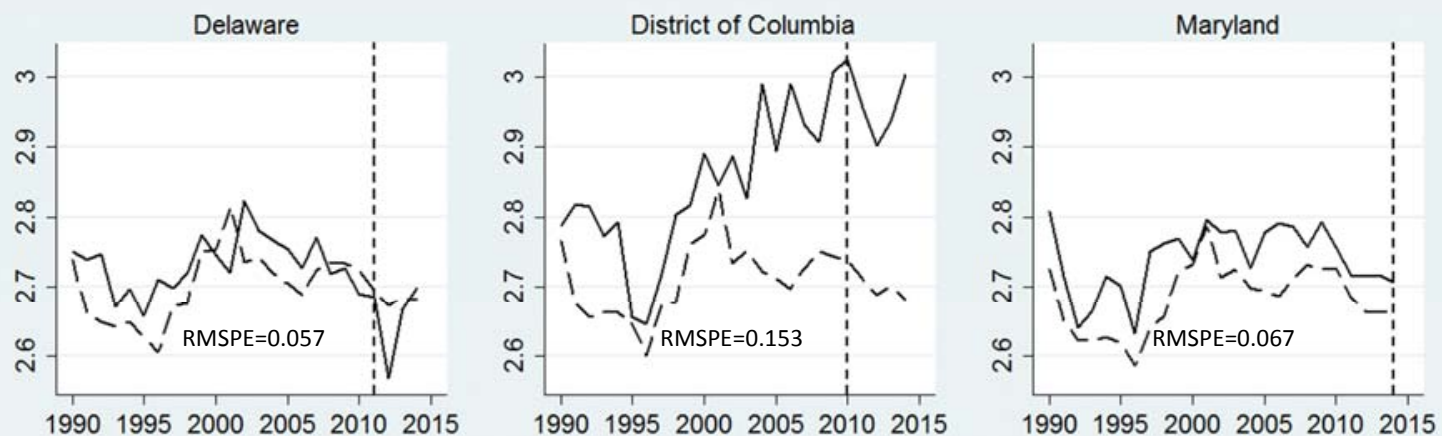

\section{MML state}

Synthetic control state

Notes: Plots come from synthetic control analysis for each state, where the synthetic control state is a linear combination of donor states that did not implement MMLs from January 1, 1990 to December 31, 2014. The vertical line denotes the year a given state's MML is enforced. RMSPE indicates the root mean square prediction error between the MML state and the synthetic control state in the pre-treatment period. 
Table 1A. Summary Statistics of Selected Variables

\begin{tabular}{|c|c|c|c|}
\hline & Pooled & Males & Females \\
\hline \multicolumn{4}{|l|}{ Dependent Variables } \\
\hline Employment & $\begin{array}{c}0.616(0.486) \\
{[6,189,607]}\end{array}$ & $\begin{array}{c}0.652(0.476) \\
{[2,979,660]}\end{array}$ & $\begin{array}{c}0.583(0.493) \\
{[3,209,947]}\end{array}$ \\
\hline Hours & $\begin{array}{c}39.223(9.874 \\
{[3,830,355]}\end{array}$ & $\begin{array}{c}41.469(9.367) \\
{[1,938,600]}\end{array}$ & $\begin{array}{c}36.799(9.834) \\
{[1,891,755]}\end{array}$ \\
\hline Wages $(2014 \$)$ & $\begin{array}{c}20.879(14.354) \\
{[3,830,355]}\end{array}$ & $\begin{array}{c}22.942(15.236) \\
{[1,938,600]}\end{array}$ & $\begin{array}{c}18.652(12.974) \\
{[1,891,755]}\end{array}$ \\
\hline \multicolumn{4}{|l|}{ Demographic Controls } \\
\hline Female & $0.509(0.500)$ & $0.000(0.000)$ & $1.000(0.000)$ \\
\hline Age & $39.573(12.891)$ & $39.402(12.872)$ & $39.739(12.907)$ \\
\hline Potential experience & $20.437(13.039)$ & $20.302(12.926)$ & $20.568(13.145)$ \\
\hline Years of education & $13.141(2.743)$ & $13.104(2.809)$ & $13.177(2.677)$ \\
\hline White & $0.693(0.461)$ & $0.697(0.459)$ & $0.688(0.463)$ \\
\hline Black & $0.119(0.324)$ & $0.110(0.313)$ & $0.128(0.334)$ \\
\hline American Indian & $0.007(0.082)$ & $0.007(0.081)$ & $0.007(0.083)$ \\
\hline Other & $0.051(0.221)$ & $0.050(0.218)$ & $0.053(0.223)$ \\
\hline Hispanic & $0.130(0.336)$ & $0.136(0.343)$ & $0.124(0.329)$ \\
\hline Married & $0.568(0.495)$ & $0.570(0.495)$ & $0.565(0.496)$ \\
\hline Widowed & $0.019(0.135)$ & $0.007(0.086)$ & $0.029(0.169)$ \\
\hline Divorced & $0.102(0.302)$ & $0.087(0.281)$ & $0.116(0.320)$ \\
\hline Separated & $0.026(0.158)$ & $0.02(0.141)$ & $0.031(0.174)$ \\
\hline Never married & $0.286(0.452)$ & $0.315(0.465)$ & $0.259(0.438)$ \\
\hline In school & $0.060(0.238)$ & $0.060(0.237)$ & $0.061(0.240)$ \\
\hline \multicolumn{4}{|l|}{ Industry Controls } \\
\hline Agriculture & $0.015(0.121)$ & $0.022(0.145)$ & $0.008(0.087)$ \\
\hline Mining & $0.006(0.074)$ & $0.009(0.095)$ & $0.002(0.041)$ \\
\hline Construction & $0.058(0.233)$ & $0.100(0.300)$ & $0.012(0.107)$ \\
\hline Manufacturing: Non-Durable & $0.060(0.238)$ & $0.071(0.257)$ & $0.048(0.215)$ \\
\hline Manufacturing: Durable & $0.092(0.290)$ & $0.131(0.337)$ & $0.051(0.220)$ \\
\hline Transportation & $0.045(0.208)$ & $0.064(0.244)$ & $0.026(0.159)$ \\
\hline Communications & $0.015(0.122)$ & $0.017(0.13)$ & $0.013(0.112)$ \\
\hline Public utilities & $0.014(0.116)$ & $0.021(0.143)$ & $0.006(0.077)$ \\
\hline Wholesale & $0.034(0.182)$ & $0.046(0.209)$ & $0.022(0.146)$ \\
\hline Retail & $0.164(0.370)$ & $0.155(0.362)$ & $0.173(0.378)$ \\
\hline Finance & $0.034(0.181)$ & $0.025(0.156)$ & $0.043(0.203)$ \\
\hline Insurance & $0.020(0.139)$ & $0.013(0.113)$ & $0.027(0.162)$ \\
\hline Real estate & $0.014(0.116)$ & $0.013(0.112)$ & $0.015(0.121)$ \\
\hline Services & $0.376(0.484)$ & $0.256(0.436)$ & $0.505(0.500)$ \\
\hline Government & $0.054(0.227)$ & $0.058(0.233)$ & $0.051(0.220)$ \\
\hline \multicolumn{4}{|c|}{ State Policy and Economic Controls } \\
\hline MML & $0.168(0.374)$ & $0.170(0.376)$ & $0.166(0.372)$ \\
\hline Marijuana decriminalization law & $0.337(0.473)$ & $0.339(0.473)$ & $0.336(0.472)$ \\
\hline Beer tax $(2014 \$)$ & $0.311(0.232)$ & $0.310(0.231)$ & $0.312(0.233)$ \\
\hline
\end{tabular}




\begin{tabular}{lccc} 
Cigarette tax (2014\$) & $0.928(0.776)$ & $0.930(0.774)$ & $0.926(0.777)$ \\
GDP per person ages 18-64 (2014\$) & $78,852.18$ & $78,882.80$ & $78,822.62$ \\
& $(14,740.58)$ & $(14,653.71)$ & $(14,823.9)$ \\
Minimum wage $(2014 \$)$ & $7.333(0.703)$ & $7.336(0.704)$ & $7.331(0.701)$ \\
\hline $\mathrm{N}$ & $6,189,607$ & $2,979,660$ & $3,209,947$ \\
\hline
\end{tabular}

Notes: Weighted means of the dependent variables, demographic controls and state controls are obtained using data from the 1990 to 2014 Current Population Survey Outgoing Rotation Groups. Standard deviations are in parentheses and number of observations in brackets. 
Table 1B. Summary Statistics of Dependent Variables by Age Groups

\begin{tabular}{|c|c|c|c|c|c|c|}
\hline & $\begin{array}{c}\text { All } \\
\text { Ages }\end{array}$ & $\begin{array}{c}\text { Ages } \\
\text { 18-to-19 }\end{array}$ & $\begin{array}{c}\text { Ages } \\
\text { 20-to-29 }\end{array}$ & $\begin{array}{c}\text { Ages } \\
\text { 30-to-39 }\end{array}$ & $\begin{array}{c}\text { Ages } \\
\text { 40-to-49 } \\
\end{array}$ & $\begin{array}{c}\text { Ages } \\
50-t 0-64 \\
\end{array}$ \\
\hline & \multicolumn{6}{|c|}{ Panel I: Pooled Sample } \\
\hline Employment & $\begin{array}{c}0.616 \\
(0.486) \\
{[6,189,607]}\end{array}$ & $\begin{array}{c}0.425 \\
(0.494) \\
{[260,249]}\end{array}$ & $\begin{array}{c}0.652 \\
(0.476) \\
{[1,289,255]}\end{array}$ & $\begin{array}{c}0.680 \\
(0.466) \\
{[1,464,569]}\end{array}$ & $\begin{array}{c}0.662 \\
(0.473) \\
{[1,480,498]}\end{array}$ & $\begin{array}{c}0.519 \\
(0.500) \\
{[1,695,036}\end{array}$ \\
\hline Hours & $\begin{array}{c}39.223 \\
(9.874 \\
{[3,830,355]}\end{array}$ & $\begin{array}{c}28.057 \\
(12.011) \\
{[114,498]}\end{array}$ & $\begin{array}{c}37.660 \\
(10.157) \\
{[851,953]}\end{array}$ & $\begin{array}{c}40.288 \\
(9.308) \\
{[997,335]}\end{array}$ & $\begin{array}{c}40.471 \\
(9.079) \\
{[983,448]}\end{array}$ & $\begin{array}{c}39.766 \\
(9.579) \\
{[883,121]}\end{array}$ \\
\hline \multirow[t]{2}{*}{ Wages $(2014 \$)$} & $\begin{array}{c}20.879 \\
(14.354) \\
{[3,830,355]}\end{array}$ & $\begin{array}{c}9.601 \\
(5.241) \\
{[114,498]}\end{array}$ & $\begin{array}{c}15.398 \\
(9.660) \\
{[851,953]}\end{array}$ & $\begin{array}{c}21.825 \\
(13.983) \\
{[997,335]}\end{array}$ & $\begin{array}{c}23.822 \\
(15.167) \\
{[983,448]}\end{array}$ & $\begin{array}{c}24.025 \\
(16.355) \\
{[883,121]}\end{array}$ \\
\hline & \multicolumn{6}{|c|}{ Panel II: Males Sample } \\
\hline Employment & $\begin{array}{c}0.652 \\
(0.476) \\
{[2,979,660]}\end{array}$ & $\begin{array}{c}0.425 \\
(0.494) \\
{[130,858]}\end{array}$ & $\begin{array}{c}0.692 \\
(0.462) \\
{[621,919]}\end{array}$ & $\begin{array}{c}0.739 \\
(0.439) \\
{[700,506]}\end{array}$ & $\begin{array}{c}0.688 \\
(0.463) \\
{[713,095]}\end{array}$ & $\begin{array}{c}0.541 \\
(0.498) \\
{[813,282]}\end{array}$ \\
\hline Hours & $\begin{array}{c}41.469 \\
(9.367) \\
{[1,938,600]}\end{array}$ & $\begin{array}{c}29.902 \\
(12.286) \\
{[57,158]}\end{array}$ & $\begin{array}{c}39.396 \\
(9.989) \\
{[436,154]}\end{array}$ & $\begin{array}{c}42.749 \\
(8.446) \\
{[516,955]}\end{array}$ & $\begin{array}{c}42.974 \\
(8.283) \\
{[489,409]}\end{array}$ & $\begin{array}{c}42.067 \\
(8.932) \\
{[438,924]}\end{array}$ \\
\hline \multirow[t]{2}{*}{ Wages $(2014 \$)$} & $\begin{array}{c}22.942 \\
(15.236) \\
{[1,938,600]}\end{array}$ & $\begin{array}{c}10.087 \\
(6.214) \\
{[57,158]}\end{array}$ & $\begin{array}{c}16.109 \\
(9.856) \\
{[436,154]}\end{array}$ & $\begin{array}{c}23.530 \\
(14.443) \\
{[516,955]}\end{array}$ & $\begin{array}{c}26.790 \\
(15.979) \\
{[489,409]}\end{array}$ & $\begin{array}{c}27.313 \\
(17.410) \\
{[438,924]}\end{array}$ \\
\hline & \multicolumn{6}{|c|}{ Panel III: Female Sample } \\
\hline Employment & $\begin{array}{c}0.583 \\
(0.493) \\
{[3,209,947]}\end{array}$ & $\begin{array}{c}0.426 \\
(0.494) \\
{[129,391]}\end{array}$ & $\begin{array}{c}0.613 \\
(0.487) \\
{[667,336]}\end{array}$ & $\begin{array}{c}0.623 \\
(0.485) \\
{[764,063]}\end{array}$ & $\begin{array}{c}0.637 \\
(0.481) \\
{[767,403]}\end{array}$ & $\begin{array}{c}0.499 \\
(0.500) \\
{[881,754]}\end{array}$ \\
\hline Hours & $\begin{array}{c}36.799 \\
(9.834) \\
{[1,891,755]}\end{array}$ & $\begin{array}{c}26.175 \\
(11.421) \\
{[57,340]}\end{array}$ & $\begin{array}{c}35.723 \\
(9.992) \\
{[415,799]}\end{array}$ & $\begin{array}{c}37.450 \\
(9.448) \\
{[480,380]}\end{array}$ & $\begin{array}{c}37.866 \\
(9.138) \\
{[494,039]}\end{array}$ & $\begin{array}{c}37.441 \\
(9.650) \\
{[438,924]}\end{array}$ \\
\hline Wages $(2014 \$)$ & $\begin{array}{c}18.652 \\
(12.974) \\
{[1,891,755]}\end{array}$ & $\begin{array}{c}9.106 \\
(3.955) \\
{[57,340]}\end{array}$ & $\begin{array}{c}14.602 \\
(9.373) \\
{[415,799]}\end{array}$ & $\begin{array}{c}19.642 \\
(13.127) \\
{[480,380]}\end{array}$ & $\begin{array}{c}20.731 \\
(11.548) \\
{[494,039]}\end{array}$ & $\begin{array}{c}20.701 \\
(14.474) \\
{[438,924]}\end{array}$ \\
\hline
\end{tabular}

Notes: Weighted means of the dependent variables are obtained using data from the 1990 to 2014 Current Population Survey Outgoing Rotation Groups. Standard deviations are in parentheses and number of observations in brackets. 
Table 2. State Medical Marijuana Law Effective Dates

\begin{tabular}{|c|c|}
\hline State & Effective Date \\
\hline Alaska & March 4,1999 \\
\hline Arizona & April 14, 2011 \\
\hline California & November 6,1996 \\
\hline Colorado & June 1, 2001 \\
\hline Connecticut & October 1,2012 \\
\hline Delaware & July 1, 2011 \\
\hline Washington, D.C. & July 26,2010 \\
\hline Hawaii & December 28,2000 \\
\hline Illinois & January 1, 2014 \\
\hline Maine & December 22,1999 \\
\hline Maryland & June 1,2014 \\
\hline Massachusetts & January 1, 2013 \\
\hline Michigan & December 4, 2008 \\
\hline Minnesota & May 30,2014 \\
\hline Montana & November 11,2004 \\
\hline Nevada & October 1,2001 \\
\hline New Hampshire & July 23,2013 \\
\hline New Jersey & October 1,2010 \\
\hline New Mexico & July 1, 2007 \\
\hline New York & July 5,2014 \\
\hline Oregon & December 3,1998 \\
\hline Rhode Island & January 3, 2006 \\
\hline Vermont & July 1, 2004 \\
\hline Washington & November 3, 1998 \\
\hline
\end{tabular}


Table 3. Difference-in-Difference Estimates of the Effect of MMLs on Employment

\begin{tabular}{|c|c|c|c|c|c|c|}
\hline & $\begin{array}{c}\text { All } \\
\text { Ages }\end{array}$ & $\begin{array}{c}\text { Ages } \\
\text { 18-to-19 }\end{array}$ & $\begin{array}{c}\text { Ages } \\
\text { 20-to-29 }\end{array}$ & $\begin{array}{c}\text { Ages } \\
30-\text { to-39 } \\
\end{array}$ & $\begin{array}{c}\text { Ages } \\
\text { 40-to-49 }\end{array}$ & $\begin{array}{c}\text { Ages } \\
50-\text { to- } 64 \\
\end{array}$ \\
\hline & \multicolumn{6}{|c|}{ Panel I: Baseline difference-in-difference estimates } \\
\hline Pooled & $\begin{array}{c}0.002 \\
(0.003)\end{array}$ & $\begin{array}{c}-0.011 \\
(0.008)\end{array}$ & $\begin{array}{c}0.002 \\
(0.004)\end{array}$ & $\begin{array}{c}0.006 \\
(0.004)\end{array}$ & $\begin{array}{c}0.004 \\
(0.004)\end{array}$ & $\begin{array}{l}-0.000 \\
(0.004)\end{array}$ \\
\hline $\mathrm{N}$ & $6,189,607$ & 260,249 & $1,289,255$ & $1,464,569$ & $1,480,498$ & $1,695,036$ \\
\hline Males & $\begin{array}{c}0.003 \\
(0.003) \\
2,979,660\end{array}$ & $\begin{array}{c}-0.011 \\
(0.012) \\
130,858\end{array}$ & $\begin{array}{c}-0.001 \\
(0.003) \\
621,919\end{array}$ & $\begin{array}{c}0.006 \\
(0.004) \\
700,506\end{array}$ & $\begin{array}{c}0.008 \\
(0.005) \\
713,095\end{array}$ & $\begin{array}{c}0.003 \\
(0.005) \\
813,282\end{array}$ \\
\hline Females & $\begin{array}{c}0.002 \\
(0.004) \\
3,209,947\end{array}$ & $\begin{array}{c}-0.010 \\
(0.009) \\
129,391\end{array}$ & $\begin{array}{c}0.005 \\
(0.006) \\
667,336\end{array}$ & $\begin{array}{c}0.006 \\
(0.005) \\
764,063\end{array}$ & $\begin{array}{c}-0.001 \\
(0.004) \\
767,403\end{array}$ & $\begin{array}{c}-0.003 \\
(0.005) \\
881,754\end{array}$ \\
\hline $\mathrm{N}$ & \multicolumn{6}{|c|}{$\begin{array}{c}\text { Panel II: Difference-in-difference estimates with state-specific linear } \\
\text { time trends }\end{array}$} \\
\hline Pooled & $\begin{array}{c}0.001 \\
(0.003) \\
6,189,607\end{array}$ & $\begin{array}{c}0.003 \\
(0.006) \\
260,249\end{array}$ & $\begin{array}{c}0.006 \\
(0.003) \\
1,289,255\end{array}$ & $\begin{array}{c}0.001 \\
(0.004) \\
1,464,569\end{array}$ & $\begin{array}{c}0.001 \\
(0.004) \\
1,480,498\end{array}$ & $\begin{array}{c}-0.002 \\
(0.004) \\
1,695,036\end{array}$ \\
\hline Males & $\begin{array}{l}0.003 \\
(0.004)\end{array}$ & $\begin{array}{c}0.008 \\
(0.010)\end{array}$ & $\begin{array}{c}0.005 \\
(0.005)\end{array}$ & $\begin{array}{c}0.004 \\
(0.005)\end{array}$ & $\begin{array}{l}0.005 \\
(0.004)\end{array}$ & $\begin{array}{l}-0.002 \\
(0.004)\end{array}$ \\
\hline $\mathrm{N}$ & $2,979,660$ & 130,858 & 621,919 & 700,506 & 713,095 & 813,282 \\
\hline Females & $\begin{array}{l}0.001 \\
(0.004)\end{array}$ & $\begin{array}{c}0.001 \\
(0.009)\end{array}$ & $\begin{array}{c}0.006 \\
(0.005)\end{array}$ & $\begin{array}{l}-0.002 \\
(0.005)\end{array}$ & $\begin{array}{c}-0.003 \\
(0.004)\end{array}$ & $\begin{array}{c}-0.001 \\
(0.006)\end{array}$ \\
\hline $\mathrm{N}$ & $3,209,947$ & 129,391 & 667,336 & 764,063 & 767,403 & 881,754 \\
\hline
\end{tabular}

**Significant at $1 \%$ level * at $5 \%$ level

Notes: Weighted OLS estimates are obtained using data from the 1990 to 2014 Current Population Survey Outgoing Rotation Groups. All regressions include state fixed effects and year fixed effects. Demographic controls include gender, race/ethnicity, age (linear and squared), education, marital status, and whether the respondent enrolls in school. State level policy and economic controls include marijuana decriminalization laws, state level alcohol and cigarette taxes, minimum wages, and per capita GDP. Standard errors corrected for clustering on the state are in parentheses. 
Table 4. Difference-in-Difference Estimates of the Effect of MMLs on Log Hours

\begin{tabular}{|c|c|c|c|c|c|c|}
\hline & $\begin{array}{c}\text { All } \\
\text { Ages }\end{array}$ & $\begin{array}{c}\text { Ages } \\
\text { 18-to-19 }\end{array}$ & $\begin{array}{c}\text { Ages } \\
20-\text { to-29 }\end{array}$ & $\begin{array}{c}\text { Ages } \\
30-\text { to-39 }\end{array}$ & $\begin{array}{c}\text { Ages } \\
40-\text { to- } 49\end{array}$ & $\begin{array}{c}\text { Ages } \\
50-\text { to-64 } \\
\end{array}$ \\
\hline & \multicolumn{6}{|c|}{ Panel I: Baseline difference-in-difference estimates } \\
\hline Pooled & $\begin{array}{l}-0.002 \\
(0.003)\end{array}$ & $\begin{array}{l}-0.004 \\
(0.008)\end{array}$ & $\begin{array}{l}-0.006 \\
(0.004)\end{array}$ & $\begin{array}{l}-0.001 \\
(0.003)\end{array}$ & $\begin{array}{c}0.000 \\
(0.002)\end{array}$ & $\begin{array}{l}-0.002 \\
(0.003)\end{array}$ \\
\hline $\mathrm{N}$ & $3,830,355$ & 114,498 & 851,953 & 997,335 & 983,448 & 883,121 \\
\hline Males & $\begin{array}{c}-0.002 \\
(0.002) \\
1,938,600\end{array}$ & $\begin{array}{c}-0.004 \\
(0.013) \\
57,158\end{array}$ & $\begin{array}{c}-0.004 \\
(0.004) \\
436,154\end{array}$ & $\begin{array}{c}-0.002 \\
(0.002) \\
516,955\end{array}$ & $\begin{array}{c}-0.001 \\
(0.002) \\
489,409\end{array}$ & $\begin{array}{c}0.001 \\
(0.003) \\
438,924\end{array}$ \\
\hline $\begin{array}{l}\text { Females } \\
\mathrm{N}\end{array}$ & $\begin{array}{c}-0.002 \\
(0.004) \\
1,891,755\end{array}$ & $\begin{array}{c}-0.002 \\
(0.009) \\
57,340 \\
\end{array}$ & $\begin{array}{c}-0.007 \\
(0.005) \\
415,799\end{array}$ & $\begin{array}{c}-0.000 \\
(0.004) \\
480,380\end{array}$ & $\begin{array}{c}0.001 \\
(0.004) \\
494,039\end{array}$ & $\begin{array}{c}-0.006 \\
(0.005) \\
444,197\end{array}$ \\
\hline $\mathrm{N}$ & \multicolumn{6}{|c|}{$\begin{array}{l}\text { Panel II: Difference-in-difference estimates with state-specific linear } \\
\text { time trends }\end{array}$} \\
\hline Pooled & $\begin{array}{c}0.001 \\
(0.002) \\
3,830,355\end{array}$ & $\begin{array}{c}0.016 \\
(0.010) \\
114,498\end{array}$ & $\begin{array}{c}0.003 \\
(0.003) \\
851,953\end{array}$ & $\begin{array}{c}-0.001 \\
(0.003) \\
997,335\end{array}$ & $\begin{array}{c}0.001 \\
(0.002) \\
983,448\end{array}$ & $\begin{array}{c}-0.001 \\
(0.002) \\
883,121\end{array}$ \\
\hline Males & $\begin{array}{c}0.000 \\
(0.002) \\
1,938,600\end{array}$ & $\begin{array}{c}0.015 \\
(0.017) \\
57,158\end{array}$ & $\begin{array}{c}0.002 \\
(0.003) \\
436,154\end{array}$ & $\begin{array}{c}-0.004 \\
(0.003) \\
516,955\end{array}$ & $\begin{array}{c}-0.001 \\
(0.002) \\
489,409\end{array}$ & $\begin{array}{c}0.002 \\
(0.003) \\
438,924\end{array}$ \\
\hline Females & $\begin{array}{c}0.002 \\
(0.002)\end{array}$ & $\begin{array}{c}0.018 \\
(0.022)\end{array}$ & $\begin{array}{c}0.003 \\
(0.004)\end{array}$ & $\begin{array}{c}0.002 \\
(0.003)\end{array}$ & $\begin{array}{l}0.003 \\
(0.004)\end{array}$ & $\begin{array}{l}-0.005 \\
(0.003)\end{array}$ \\
\hline $\mathrm{N}$ & $1,891,755$ & 57,340 & 415,799 & 480,380 & 494,039 & 444,197 \\
\hline
\end{tabular}

**Significant at $1 \%$ level * at $5 \%$ level

Notes: Weighted OLS estimates are obtained using data from the 1990 to 2014 Current Population Survey Outgoing Rotation Groups. All regressions include state fixed effects and year fixed effects. Demographic controls include gender, race/ethnicity, age (linear and squared), education, marital status, industry classification, and whether the respondent enrolls in school. State level policy and economic controls include marijuana decriminalization laws, state level alcohol and cigarette taxes, minimum wages, and per capita GDP. Standard errors corrected for clustering on the state are in parentheses. 
Table 5. Difference-in-Difference Estimates of the Effect of MMLs on Log Wages

\begin{tabular}{|c|c|c|c|c|c|c|}
\hline & $\begin{array}{c}\text { All } \\
\text { Ages }\end{array}$ & $\begin{array}{c}\text { Ages } \\
\text { 18-to-19 }\end{array}$ & $\begin{array}{c}\text { Ages } \\
\text { 20-to-29 } \\
\end{array}$ & $\begin{array}{c}\text { Ages } \\
\text { 30-to-39 }\end{array}$ & $\begin{array}{c}\text { Ages } \\
\text { 40-to-49 }\end{array}$ & $\begin{array}{c}\text { Ages } \\
50-\text { to-64 } \\
\end{array}$ \\
\hline & \multicolumn{6}{|c|}{ Panel I: Baseline difference-in-difference estimates } \\
\hline Pooled & $\begin{array}{l}-0.010 \\
(0.009)\end{array}$ & $\begin{array}{c}-0.002 \\
(0.005)\end{array}$ & $\begin{array}{l}-0.021 \\
(0.012)\end{array}$ & $\begin{array}{c}-0.011 \\
(0.011)\end{array}$ & $\begin{array}{l}-0.005 \\
(0.007)\end{array}$ & $\begin{array}{l}-0.003 \\
(0.010)\end{array}$ \\
\hline $\mathrm{N}$ & $3,830,355$ & 114,498 & 851,953 & 997,335 & 983,448 & 883,121 \\
\hline Males & $\begin{array}{c}-0.010 \\
(0.010) \\
1,938,600\end{array}$ & $\begin{array}{c}-0.009 \\
(0.006) \\
57,158\end{array}$ & $\begin{array}{c}-0.025^{*} \\
(0.012) \\
436,154\end{array}$ & $\begin{array}{c}-0.013 \\
(0.012) \\
516,955\end{array}$ & $\begin{array}{c}-0.000 \\
(0.009) \\
489,409\end{array}$ & $\begin{array}{c}-0.001 \\
(0.012) \\
438,924\end{array}$ \\
\hline $\begin{array}{l}\text { Females } \\
\mathrm{N}\end{array}$ & $\begin{array}{c}-0.009 \\
(0.008) \\
1,891,755\end{array}$ & $\begin{array}{c}0.005 \\
(0.007) \\
57,340\end{array}$ & $\begin{array}{c}-0.015 \\
(0.011) \\
415,799\end{array}$ & $\begin{array}{c}-0.008 \\
(0.010) \\
480,380\end{array}$ & $\begin{array}{c}-0.010 \\
(0.007) \\
494,039\end{array}$ & $\begin{array}{c}-0.005 \\
(0.008) \\
444,197\end{array}$ \\
\hline $\mathrm{N}$ & \multicolumn{6}{|c|}{$\begin{array}{c}\text { Panel II: Difference-in-difference estimates with state-specific linear } \\
\text { time trends }\end{array}$} \\
\hline Pooled & $\begin{array}{c}-0.010 \\
(0.007) \\
3,830,355\end{array}$ & $\begin{array}{c}-0.006 \\
(0.010) \\
114,498\end{array}$ & $\begin{array}{c}-0.018 \\
(0.010) \\
851,953\end{array}$ & $\begin{array}{c}-0.011 \\
(0.011) \\
997,335\end{array}$ & $\begin{array}{c}-0.005 \\
(0.006) \\
983,448\end{array}$ & $\begin{array}{c}-0.006 \\
(0.005) \\
883,121\end{array}$ \\
\hline Males & $\begin{array}{c}-0.010 \\
(0.008) \\
1,938,600\end{array}$ & $\begin{array}{c}-0.007 \\
(0.010) \\
57,158\end{array}$ & $\begin{array}{c}-0.028 * \\
(0.012) \\
436,154\end{array}$ & $\begin{array}{c}-0.014 \\
(0.012) \\
516,955\end{array}$ & $\begin{array}{c}0.001 \\
(0.005) \\
489,409\end{array}$ & $\begin{array}{c}-0.002 \\
(0.006) \\
438,924\end{array}$ \\
\hline Females & $\begin{array}{l}-0.010 \\
(0.007)\end{array}$ & $\begin{array}{l}-0.004 \\
(0.013)\end{array}$ & $\begin{array}{l}-0.007 \\
(0.009)\end{array}$ & $\begin{array}{l}-0.008 \\
(0.012)\end{array}$ & $\begin{array}{l}-0.012 \\
(0.007)\end{array}$ & $\begin{array}{l}-0.011 \\
(0.007)\end{array}$ \\
\hline $\mathrm{N}$ & $1,891,755$ & 57,340 & 415,799 & 480,380 & 494,039 & 444,197 \\
\hline
\end{tabular}

**Significant at $1 \%$ level * at $5 \%$ level

Notes: Weighted OLS estimates are obtained using data from the 1990 to 2014 Current Population Survey Outgoing Rotation Groups. All regressions include state fixed effects and year fixed effects. Demographic controls include gender, race/ethnicity, potential experience (linear and squared), education, marital status, industry classification, and whether the respondent enrolls in school. State level policy and economic controls include marijuana decriminalization laws, state level alcohol and cigarette taxes, minimum wages, and per capita GDP. Standard errors corrected for clustering on the state are in parentheses. 
Table 6. Robustness of Estimates to Control for Anti-Marijuana Legalization Sentiment

\begin{tabular}{|c|c|c|c|c|c|c|}
\hline & $\begin{array}{c}\text { All } \\
\text { Ages }\end{array}$ & $\begin{array}{c}\text { Ages } \\
\text { 18-to-19 }\end{array}$ & $\begin{array}{c}\text { Ages } \\
\text { 20-to-29 }\end{array}$ & $\begin{array}{c}\text { Ages } \\
\text { 30-to-39 }\end{array}$ & $\begin{array}{c}\text { Ages } \\
40-\text { to-49 }\end{array}$ & $\begin{array}{c}\text { Ages } \\
50-\text { to-64 }\end{array}$ \\
\hline & \multicolumn{6}{|c|}{ Panel I: Pooled Sample } \\
\hline Employment & $\begin{array}{c}0.002 \\
(0.003)\end{array}$ & $\begin{array}{c}0.002 \\
(0.006)\end{array}$ & $\begin{array}{c}0.006 \\
(0.003)\end{array}$ & $\begin{array}{c}0.001 \\
(0.004)\end{array}$ & $\begin{array}{c}0.001 \\
(0.004)\end{array}$ & $\begin{array}{c}-0.002 \\
(0.004)\end{array}$ \\
\hline $\mathrm{N}$ & $6,013,148$ & 252,964 & $1,251,894$ & $1,422,844$ & $1,438,119$ & $1,647,327$ \\
\hline Hours & $\begin{array}{c}0.003 \\
(0.004)\end{array}$ & $\begin{array}{c}0.008 \\
(0.011)\end{array}$ & $\begin{array}{c}0.005 \\
(0.005)\end{array}$ & $\begin{array}{c}0.004 \\
(0.005)\end{array}$ & $\begin{array}{c}0.005 \\
(0.004)\end{array}$ & $\begin{array}{l}-0.001 \\
(0.004)\end{array}$ \\
\hline $\mathrm{N}$ & $3,714,767$ & 110,631 & 825,393 & 967,815 & 954,140 & 856,788 \\
\hline Wages & $\begin{array}{l}0.001 \\
(0.004)\end{array}$ & $\begin{array}{l}-0.002 \\
(0.009)\end{array}$ & $\begin{array}{c}0.007 \\
(0.005)\end{array}$ & $\begin{array}{l}-0.002 \\
(0.005)\end{array}$ & $\begin{array}{l}-0.003 \\
(0.004)\end{array}$ & $\begin{array}{l}-0.001 \\
(0.006)\end{array}$ \\
\hline \multirow[t]{2}{*}{$\mathrm{N}$} & $3,714,767$ & 110,631 & 825,393 & 967,815 & 954,140 & 856,788 \\
\hline & \multicolumn{6}{|c|}{ Panel II: Males } \\
\hline Employment & $\begin{array}{c}0.002 \\
(0.002)\end{array}$ & $\begin{array}{c}0.012 \\
(0.010)\end{array}$ & $\begin{array}{c}0.002 \\
(0.003)\end{array}$ & $\begin{array}{l}-0.003 \\
(0.003)\end{array}$ & $\begin{array}{c}0.005 \\
(0.002)\end{array}$ & $\begin{array}{c}0.006 \\
(0.004)\end{array}$ \\
\hline $\mathrm{N}$ & $2,892,780$ & 127,186 & 603,679 & 679,955 & 692,118 & 789,842 \\
\hline Hours & $\begin{array}{l}-0.000 \\
(0.002)\end{array}$ & $\begin{array}{c}0.015 \\
(0.017)\end{array}$ & $\begin{array}{c}0.002 \\
(0.003)\end{array}$ & $\begin{array}{l}-0.004 \\
(0.003)\end{array}$ & $\begin{array}{l}-0.002 \\
(0.002)\end{array}$ & $\begin{array}{c}0.002 \\
(0.003)\end{array}$ \\
\hline $\mathrm{N}$ & $1,879,174$ & 55,219 & 422,395 & 501,257 & 474,559 & 425,744 \\
\hline Wages & $\begin{array}{l}-0.010 \\
(0.008)\end{array}$ & $\begin{array}{l}-0.007 \\
(0.010)\end{array}$ & $\begin{array}{c}-0.028 * \\
(0.012)\end{array}$ & $\begin{array}{l}-0.014 \\
(0.012)\end{array}$ & $\begin{array}{c}0.001 \\
(0.005)\end{array}$ & $\begin{array}{c}-0.002 \\
(0.006)\end{array}$ \\
\hline \multirow[t]{2}{*}{$\mathrm{N}$} & $1,879,174$ & 55,219 & 422,395 & 501,257 & 474,559 & 425,744 \\
\hline & \multicolumn{6}{|c|}{ Panel III: Females } \\
\hline Employment & $\begin{array}{c}0.000 \\
(0.003)\end{array}$ & $\begin{array}{c}0.001 \\
(0.007)\end{array}$ & $\begin{array}{c}0.004 \\
(0.004)\end{array}$ & $\begin{array}{c}-0.002 \\
(0.004)\end{array}$ & $\begin{array}{l}-0.004 \\
(0.002)\end{array}$ & $\begin{array}{c}-0.002 \\
(0.005)\end{array}$ \\
\hline $\mathrm{N}$ & $3,120,368$ & 125,778 & 648,215 & 742,889 & 746,001 & 857,485 \\
\hline Hours & $\begin{array}{c}0.002 \\
(0.002)\end{array}$ & $\begin{array}{c}0.017 \\
(0.023)\end{array}$ & $\begin{array}{c}0.004 \\
(0.004)\end{array}$ & $\begin{array}{c}0.002 \\
(0.003)\end{array}$ & $\begin{array}{c}0.003 \\
(0.004)\end{array}$ & $\begin{array}{l}-0.005 \\
(0.003)\end{array}$ \\
\hline $\mathrm{N}$ & $1,835,593$ & 55,412 & 402,998 & 466,558 & 479,581 & 431,044 \\
\hline Wages & $\begin{array}{l}-0.010 \\
(0.007)\end{array}$ & $\begin{array}{c}-0.004 \\
(0.013)\end{array}$ & $\begin{array}{l}-0.008 \\
(0.009)\end{array}$ & $\begin{array}{l}-0.007 \\
(0.012)\end{array}$ & $\begin{array}{l}-0.013 \\
(0.007)\end{array}$ & $\begin{array}{l}-0.011 \\
(0.007)\end{array}$ \\
\hline $\mathrm{N}$ & $1,835,593$ & 55,412 & 402,998 & 466,558 & 479,581 & 431,044 \\
\hline
\end{tabular}

**Significant at $1 \%$ level * at $5 \%$ level

Notes: Weighted OLS estimates are obtained using data from the 1990 to 2014 Current Population Survey Outgoing Rotation Groups. All regressions include state fixed effects, year fixed effects and state specific linear time trends. Demographic controls include gender, race/ethnicity, age (linear and squared)/potential experience (linear and squared), education, marital status, industry classification, and whether the respondent enrolls in school. State level policy and economic controls include marijuana decriminalization laws, state level alcohol and cigarette taxes, minimum wages, and per capita GDP. Standard errors corrected for clustering on the state are in parentheses. 
Table 7. Robustness of Estimates of the Effect of MMLs on Log Wages to Controls for Policy Leads and Lags

\begin{tabular}{|c|c|c|c|c|c|c|}
\hline & $\begin{array}{c}\text { All } \\
\text { Ages }\end{array}$ & $\begin{array}{c}\text { Ages } \\
\text { 18-to-19 }\end{array}$ & $\begin{array}{c}\text { Ages } \\
20-\text { to- } 29\end{array}$ & $\begin{array}{c}\text { Ages } \\
\text { 30-to-39 } \\
\end{array}$ & $\begin{array}{c}\text { Ages } \\
40-\text { to- } 49\end{array}$ & $\begin{array}{c}\text { Ages } \\
50-t 0-64 \\
\end{array}$ \\
\hline & \multicolumn{6}{|c|}{ Panel I: Pooled Sample } \\
\hline \multirow[t]{2}{*}{4 Years Prior } & 0.009 & 0.011 & 0.012 & $0.014 *$ & 0.008 & 0.009 \\
\hline & $(0.004)$ & $(0.009)$ & $(0.007)$ & $(0.007)$ & $(0.006)$ & $(0.004)$ \\
\hline \multirow[t]{2}{*}{3 Years Prior } & 0.003 & -0.007 & -0.000 & -0.007 & 0.009 & 0.003 \\
\hline & $(0.005)$ & $(0.013)$ & $(0.008)$ & $(0.007)$ & $(0.007)$ & $(0.005)$ \\
\hline \multirow[t]{2}{*}{2 Years Prior } & 0.001 & 0.024 & -0.006 & 0.001 & 0.006 & 0.001 \\
\hline & $(0.009)$ & $(0.023)$ & $(0.010)$ & $(0.012)$ & $(0.012)$ & $(0.009)$ \\
\hline \multirow[t]{2}{*}{1 Year Prior } & 0.002 & 0.015 & -0.008 & 0.000 & 0.004 & 0.002 \\
\hline & $(0.009)$ & $(0.022)$ & $(0.008)$ & $(0.013)$ & $(0.012)$ & $(0.009)$ \\
\hline \multirow[t]{2}{*}{ Year of law changed } & -0.004 & -0.000 & -0.008 & 0.002 & -0.008 & -0.004 \\
\hline & $(0.012)$ & $(0.021)$ & $(0.015)$ & $(0.015)$ & $(0.011)$ & $(0.012)$ \\
\hline \multirow[t]{2}{*}{1 Year After } & -0.005 & 0.004 & -0.009 & -0.004 & -0.004 & -0.005 \\
\hline & $(0.014)$ & $(0.023)$ & $(0.014)$ & $(0.025)$ & $(0.010)$ & $(0.014)$ \\
\hline \multirow[t]{2}{*}{2 Years After } & -0.016 & -0.005 & -0.018 & -0.028 & -0.006 & -0.016 \\
\hline & $(0.012)$ & $(0.027)$ & $(0.013)$ & $(0.016)$ & $(0.012)$ & $(0.012)$ \\
\hline \multirow[t]{2}{*}{$3+$ Years After } & -0.009 & 0.025 & -0.005 & -0.009 & -0.014 & -0.009 \\
\hline & $(0.009)$ & $(0.032)$ & $(0.010)$ & $(0.012)$ & $(0.010)$ & $(0.009)$ \\
\hline$\chi^{2}$ of $\sum\left(\beta_{\text {leads }}\right)=0$ & 0.364 & 0.574 & 0.012 & 0.050 & 0.766 & 2.065 \\
\hline p-value & 0.549 & 0.452 & 0.914 & 0.824 & 0.386 & 0.157 \\
\hline$\chi^{2}$ of $\sum\left(\beta_{\text {yrchange, }}, \beta_{\text {lags }}\right)=0$ & 0.592 & 0.069 & 0.815 & 0.410 & 0.642 & 0.322 \\
\hline p-value & 0.445 & 0.794 & 0.371 & 0.525 & 0.427 & 0.573 \\
\hline \multirow[t]{2}{*}{$\mathrm{N}$} & $3,830,355$ & 114,498 & 851,953 & 997,335 & 983,448 & 883,121 \\
\hline & \multicolumn{6}{|c|}{ Panel II: Males } \\
\hline \multirow[t]{2}{*}{4 Years Prior } & 0.004 & 0.015 & -0.008 & 0.007 & $0.013^{*}$ & 0.003 \\
\hline & $(0.006)$ & $(0.012)$ & $(0.007)$ & $(0.007)$ & $(0.006)$ & $(0.012)$ \\
\hline \multirow[t]{2}{*}{3 Years Prior } & 0.003 & -0.012 & -0.008 & 0.012 & 0.005 & 0.003 \\
\hline & $(0.008)$ & $(0.013)$ & $(0.012)$ & $(0.006)$ & $(0.013)$ & $(0.008)$ \\
\hline \multirow[t]{2}{*}{2 Years Prior } & -0.001 & -0.005 & -0.027 & 0.004 & 0.007 & 0.013 \\
\hline & $(0.007)$ & $(0.019)$ & $(0.014)$ & $(0.005)$ & $(0.007)$ & $(0.009)$ \\
\hline \multirow[t]{2}{*}{1 Year Prior } & -0.011 & -0.012 & -0.029 & -0.014 & -0.014 & 0.017 \\
\hline & $(0.014)$ & $(0.023)$ & $(0.015)$ & $(0.012)$ & $(0.012)$ & $(0.016)$ \\
\hline \multirow[t]{2}{*}{ Year of law changed } & -0.010 & -0.008 & $-0.043^{*}$ & -0.008 & -0.000 & 0.010 \\
\hline & $(0.014)$ & $(0.019)$ & $(0.018)$ & $(0.015)$ & $(0.012)$ & $(0.012)$ \\
\hline \multirow[t]{2}{*}{1 Year After } & -0.009 & -0.017 & -0.032 & -0.016 & 0.009 & -0.000 \\
\hline & $(0.016)$ & $(0.023)$ & $(0.022)$ & $(0.017)$ & $(0.013)$ & $(0.018)$ \\
\hline \multirow[t]{2}{*}{2 Years After } & -0.019 & -0.010 & $-0.056^{*}$ & -0.026 & 0.001 & 0.005 \\
\hline & $(0.016)$ & $(0.017)$ & $(0.021)$ & $(0.023)$ & $(0.012)$ & $(0.010)$ \\
\hline \multirow[t]{2}{*}{ 3+ Years After } & -0.010 & -0.005 & $-0.038 *$ & -0.011 & 0.000 & 0.006 \\
\hline & $(0.012)$ & $(0.025)$ & $(0.018)$ & $(0.014)$ & $(0.011)$ & $(0.012)$ \\
\hline
\end{tabular}




\begin{tabular}{|c|c|c|c|c|c|c|}
\hline & $\begin{array}{c}\text { All } \\
\text { Ages }\end{array}$ & $\begin{array}{c}\text { Ages } \\
\text { 18-to-19 }\end{array}$ & $\begin{array}{c}\text { Ages } \\
20-\text { to- } 29\end{array}$ & $\begin{array}{c}\text { Ages } \\
\text { 30-to-39 }\end{array}$ & $\begin{array}{c}\text { Ages } \\
40-\text { to- } 49\end{array}$ & $\begin{array}{c}\text { Ages } \\
50-\text { to-64 } \\
\end{array}$ \\
\hline$\chi^{2}$ of $\sum\left(\beta_{\text {leads }}\right)=0$ & 0.03 & 0.058 & 2.547 & 0.125 & 0.109 & 0.883 \\
\hline p-value & 0.864 & 0.811 & 0.117 & 0.725 & 0.743 & 0.352 \\
\hline$\chi^{2}$ of $\sum\left(\beta_{\text {yrchange }}, \beta_{\text {lags }}\right)=0$ & 0.772 & 0.28 & 4.798 & 0.955 & 0.051 & 0.205 \\
\hline p-value & 0.384 & 0.599 & 0.033 & 0.333 & 0.822 & 0.653 \\
\hline \multirow[t]{2}{*}{$\mathrm{N}$} & $1,938,600$ & 57,158 & 436,154 & 516,955 & 489,409 & 438,924 \\
\hline & \multicolumn{6}{|c|}{ Panel III: Females } \\
\hline 4 Years Prior & $\begin{array}{c}0.009 \\
(0.004)\end{array}$ & $\begin{array}{c}0.011 \\
(0.009)\end{array}$ & $\begin{array}{c}0.012 \\
(0.007)\end{array}$ & $\begin{array}{l}0.014^{*} \\
(0.007)\end{array}$ & $\begin{array}{c}0.008 \\
(0.006)\end{array}$ & $\begin{array}{c}0.007 \\
(0.007)\end{array}$ \\
\hline 3 Years Prior & $\begin{array}{c}0.003 \\
(0.005)\end{array}$ & $\begin{array}{l}-0.007 \\
(0.013)\end{array}$ & $\begin{array}{l}-0.000 \\
(0.008)\end{array}$ & $\begin{array}{l}-0.007 \\
(0.007)\end{array}$ & $\begin{array}{c}0.009 \\
(0.007)\end{array}$ & $\begin{array}{c}0.015 * * \\
(0.005)\end{array}$ \\
\hline 2 Years Prior & $\begin{array}{c}0.001 \\
(0.009)\end{array}$ & $\begin{array}{c}0.024 \\
(0.023)\end{array}$ & $\begin{array}{l}-0.006 \\
(0.010)\end{array}$ & $\begin{array}{c}0.001 \\
(0.012)\end{array}$ & $\begin{array}{c}0.006 \\
(0.012)\end{array}$ & $\begin{array}{c}0.002 \\
(0.007)\end{array}$ \\
\hline 1 Year Prior & $\begin{array}{c}0.002 \\
(0.009)\end{array}$ & $\begin{array}{c}0.015 \\
(0.022)\end{array}$ & $\begin{array}{l}-0.008 \\
(0.008)\end{array}$ & $\begin{array}{c}0.000 \\
(0.013)\end{array}$ & $\begin{array}{c}0.004 \\
(0.012)\end{array}$ & $\begin{array}{c}0.012 \\
(0.010)\end{array}$ \\
\hline Year of law changed & $\begin{array}{l}-0.004 \\
(0.012)\end{array}$ & $\begin{array}{l}-0.000 \\
(0.021)\end{array}$ & $\begin{array}{l}-0.008 \\
(0.015)\end{array}$ & $\begin{array}{c}0.002 \\
(0.015)\end{array}$ & $\begin{array}{l}-0.008 \\
(0.011)\end{array}$ & $\begin{array}{l}-0.001 \\
(0.013)\end{array}$ \\
\hline 1 Year After & $\begin{array}{l}-0.005 \\
(0.014)\end{array}$ & $\begin{array}{c}0.004 \\
(0.023)\end{array}$ & $\begin{array}{l}-0.009 \\
(0.014)\end{array}$ & $\begin{array}{l}-0.004 \\
(0.025)\end{array}$ & $\begin{array}{l}-0.004 \\
(0.010)\end{array}$ & $\begin{array}{c}0.002 \\
(0.012)\end{array}$ \\
\hline 2 Years After & $\begin{array}{l}-0.016 \\
(0.012)\end{array}$ & $\begin{array}{l}-0.005 \\
(0.027)\end{array}$ & $\begin{array}{l}-0.018 \\
(0.013)\end{array}$ & $\begin{array}{l}-0.028 \\
(0.016)\end{array}$ & $\begin{array}{l}-0.006 \\
(0.012)\end{array}$ & $\begin{array}{l}-0.013 \\
(0.009)\end{array}$ \\
\hline $3+$ Years After & $\begin{array}{l}-0.009 \\
(0.009)\end{array}$ & $\begin{array}{c}0.025 \\
(0.032)\end{array}$ & $\begin{array}{l}-0.005 \\
(0.010)\end{array}$ & $\begin{array}{l}-0.009 \\
(0.012)\end{array}$ & $\begin{array}{l}-0.014 \\
(0.010)\end{array}$ & $\begin{array}{l}-0.009 \\
(0.010)\end{array}$ \\
\hline$\chi^{2}$ of $\sum\left(\beta_{\text {leads }}\right)=0$ & 0.364 & 0.574 & 0.012 & 0.05 & 0.766 & 2.065 \\
\hline p-value & 0.549 & 0.452 & 0.914 & 0.824 & 0.386 & 0.157 \\
\hline$\chi^{2}$ of $\sum\left(\beta_{\text {yrchange, }} \beta_{\text {lags }}\right)=0$ & 0.592 & 0.069 & 0.815 & 0.41 & 0.642 & 0.322 \\
\hline p-value & 0.445 & 0.794 & 0.371 & 0.525 & 0.427 & 0.573 \\
\hline $\mathrm{N}$ & $1,891,755$ & 57,340 & 415,799 & 480,380 & 494,039 & 444,197 \\
\hline $\begin{array}{l}\text { **Significant at } 1 \% \text { level } * \\
\text { Notes: Weighted OLS estim } \\
\text { Rotation Groups. All regress } \\
\text { Demographic controls incluc } \\
\text { squared), education, marital } \\
\text { policy and economic control } \\
\text { minimum wages, and per cal }\end{array}$ & $\begin{array}{l}\text { btained using } \\
\text { ide state fixed } \\
\text { race/ethnicity } \\
\text { dustry classific }\end{array}$ & $\begin{array}{l}\text { effects, yea } \\
\text {, age (linea }\end{array}$ & $\begin{array}{l}\text { fixed effect } \\
\text { and squared }\end{array}$ & $\begin{array}{l}\text { Current } \mathrm{P} \\
\text { and state st } \\
\text { potential e }\end{array}$ & $\begin{array}{l}\text { lation } \mathrm{Su} \\
\text { fic linear } \\
\text { rience (lir }\end{array}$ & $\begin{array}{l}\text { y Outgoing } \\
\text { le trends. } \\
\text { and } \\
\text { State level } \\
\text { axes, } \\
\text { ses. }\end{array}$ \\
\hline
\end{tabular}


Table 8. Synthetic Difference-in-Difference Estimates of the Effect of MMLs on Log Wages for Males Ages 20-to-29

\begin{tabular}{|c|c|c|c|}
\hline \multicolumn{4}{|c|}{ Northeastern States } \\
\hline Connecticut & Maine & Massachusetts & New Hampshire \\
\hline-0.048 & -0.027 & -0.022 & -0.041 \\
\hline$(0.066)$ & $(0.020)$ & $(0.058)$ & $(0.034)$ \\
\hline$\{0.786\}$ & $\{0.750\}$ & $\{0.571\}$ & $\{0.929\}$ \\
\hline$[75]$ & {$[200]$} & {$[50]$} & {$[100]$} \\
\hline New Jersey & New York & Rhode Island & Vermont \\
\hline-0.065 & -0.005 & -0.030 & -0.021 \\
\hline$(0.046)$ & $(0.028)$ & $(0.027)$ & $(0.021)$ \\
\hline$\{0.964\}$ & $\{0.643\}$ & $\{0.929\}$ & $\{0.143\}$ \\
\hline [75] & {$[75]$} & [75] & {$[150]$} \\
\hline \multicolumn{4}{|c|}{ Western States } \\
\hline Alaska & Arizona & California & Colorado \\
\hline$-0.080 * *$ & 0.005 & -0.015 & $0.039 *$ \\
\hline$(0.029)$ & $(0.018)$ & $(0.016)$ & $(0.017)$ \\
\hline$\{0.964\}$ & $\{0.464\}$ & $\{0.964\}$ & $\{0.964\}$ \\
\hline$[75]$ & {$[175]$} & {$[100]$} & {$[125]$} \\
\hline Hawaii & Montana & Nevada & New Mexico \\
\hline-0.058 & -0.008 & -0.038 & 0.002 \\
\hline$(0.043)$ & $(0.015)$ & $(0.024)$ & $(0.035)$ \\
\hline$\{0.929\}$ & $\{0.679\}$ & $\{0.929\}$ & $\{0.179\}$ \\
\hline \multirow[t]{6}{*}[50]{} & {$[150]$} & {$[75]$} & {$[125]$} \\
\hline & Oregon & Washington & \\
\hline & -0.007 & 0.007 & \\
\hline & $(0.012)$ & $(0.017)$ & \\
\hline & $\{0.643\}$ & $\{0.964\}$ & \\
\hline & {$[175]$} & {$[100]$} & \\
\hline \multicolumn{4}{|c|}{ Mid-Western States } \\
\hline Illinois & & & Minnesota \\
\hline-0.054 & & & -0.035 \\
\hline$(0.039)$ & & & $(0.030)$ \\
\hline$\{0.500\}$ & & & $\{0.964\}$ \\
\hline$[75]$ & & & {$[125]$} \\
\hline \multicolumn{4}{|c|}{ Southern States } \\
\hline Delaware & Dist & umbia & Maryland \\
\hline-0.067 & & & -0.024 \\
\hline$(0.037)$ & & & $(0.072)$ \\
\hline$\{0.750\}$ & & & $\{0.679\}$ \\
\hline [100] & & & [100] \\
\hline
\end{tabular}

**Significant at $1 \%$ level $*$ at $5 \%$ level

Notes: Weighted OLS estimates are obtained using state-year data from the 1990 to 2014 Current Population Survey Outgoing Rotation Groups. All regressions include state fixed effects and year fixed effects. Control states are selected by the procedure developed by Abadie et al. (2010) and regressions are weighted using the synthetic control weights. Wild bootstrapped standard errors are in parentheses, p-values calculated based on a raking of states of the ratio post-mean-squared-prediction-error to the pre-mean-squared-predicting error after implementing the synthetic approach for each of the potential donor states in braces, and the number of observations in brackets. 
Table 9. Exploring Mechanisms-Difference-in-Difference Estimates of the Effect of MMLs on Exercising and Drinking, BRFSS 1990-2013

\begin{tabular}{|c|c|c|c|c|c|c|}
\hline & $\begin{array}{c}\text { All } \\
\text { Ages }\end{array}$ & $\begin{array}{c}\text { Ages } \\
\text { 18-to-19 }\end{array}$ & $\begin{array}{c}\text { Ages } \\
20-\text { to-29 }\end{array}$ & $\begin{array}{c}\text { Ages } \\
30-\text { to-39 }\end{array}$ & $\begin{array}{c}\text { Ages } \\
40-\text { to- } 49\end{array}$ & $\begin{array}{c}\text { Ages } \\
50-\text { to-64 }\end{array}$ \\
\hline & \multicolumn{6}{|c|}{ Panel I: Pooled Sample } \\
\hline Vigorous Days & $\begin{array}{c}0.003 \\
(0.018)\end{array}$ & $\begin{array}{l}-0.144 \\
(0.083)\end{array}$ & $\begin{array}{c}-0.054^{* *} \\
(0.020)\end{array}$ & $\begin{array}{l}-0.025 \\
(0.020)\end{array}$ & $\begin{array}{c}0.020 \\
(0.030)\end{array}$ & $\begin{array}{c}0.024 \\
(0.027)\end{array}$ \\
\hline Mean & 1.559 & 2.501 & 1.942 & 1.723 & 1.589 & 1.288 \\
\hline $\mathrm{N}$ & $1,225,377$ & 21,728 & 151,783 & 250,240 & 317,107 & 484,519 \\
\hline Number of Drinks & $\begin{array}{c}-0.656^{*} \\
(0.297)\end{array}$ & $\begin{array}{l}-1.076 \\
(0.922)\end{array}$ & $\begin{array}{c}-1.749 * * \\
(0.491)\end{array}$ & $\begin{array}{l}-0.679 \\
(0.481)\end{array}$ & $\begin{array}{l}-0.385 \\
(0.390)\end{array}$ & $\begin{array}{c}-0.471 \\
(0.246)\end{array}$ \\
\hline Mean & 11.482 & 10.171 & 14.121 & 11.066 & 11.590 & 10.793 \\
\hline \multirow[t]{2}{*}{$\mathrm{N}$} & $3,725,215$ & 73,072 & 498,919 & 783,972 & 925,599 & $1,443,653$ \\
\hline & \multicolumn{6}{|c|}{ Panel II: Males } \\
\hline Vigorous Days & $\begin{array}{c}0.014 \\
(0.031)\end{array}$ & $\begin{array}{c}-0.189 * * \\
(0.071)\end{array}$ & $\begin{array}{c}-0.080 \\
(0.044)\end{array}$ & $\begin{array}{c}0.039 \\
(0.032)\end{array}$ & $\begin{array}{c}0.012 \\
(0.060)\end{array}$ & $\begin{array}{c}0.028 \\
(0.029)\end{array}$ \\
\hline Mean & 1.865 & 3.086 & 2.400 & 2.067 & 1.858 & 1.535 \\
\hline $\mathrm{N}$ & 486,220 & 10,539 & 59,583 & 96,715 & 126,862 & 192,521 \\
\hline Number of Drinks & $\begin{array}{l}-0.744 \\
(0.465)\end{array}$ & $\begin{array}{l}-3.115^{*} \\
(1.527)\end{array}$ & $\begin{array}{c}-2.581 * * \\
(0.937)\end{array}$ & $\begin{array}{l}-0.746 \\
(0.687)\end{array}$ & $\begin{array}{l}-0.464 \\
(0.718)\end{array}$ & $\begin{array}{l}-0.389 \\
(0.402)\end{array}$ \\
\hline Mean & 18.350 & 14.598 & 23.440 & 18.274 & 17.939 & 17.114 \\
\hline \multirow[t]{2}{*}{$\mathrm{N}$} & $1,470,496$ & 34,572 & 197,744 & 301,411 & 367,472 & 569,297 \\
\hline & \multicolumn{6}{|c|}{ Panel III: Females } \\
\hline Vigorous Days & $\begin{array}{l}-0.004 \\
(0.018)\end{array}$ & $\begin{array}{l}-0.106 \\
(0.113)\end{array}$ & $\begin{array}{c}-0.033 \\
(0.029)\end{array}$ & $\begin{array}{c}-0.069^{*} \\
(0.029)\end{array}$ & $\begin{array}{c}0.021 \\
(0.021)\end{array}$ & $\begin{array}{c}0.030 \\
(0.045)\end{array}$ \\
\hline Mean & 1.358 & 1.949 & 1.645 & 1.522 & 1.410 & 1.125 \\
\hline $\mathrm{N}$ & 739,157 & 11,189 & 92,200 & 153,525 & 190,245 & 291,998 \\
\hline Number of Drinks & $\begin{array}{c}-0.363 * * \\
(0.136)\end{array}$ & $\begin{array}{c}0.299 \\
(1.388)\end{array}$ & $\begin{array}{c}-0.987 * * \\
(0.259)\end{array}$ & $\begin{array}{l}-0.282 \\
(0.285)\end{array}$ & $\begin{array}{l}-0.045 \\
(0.201)\end{array}$ & $\begin{array}{c}-0.361^{*} \\
(0.159)\end{array}$ \\
\hline Mean & 6.879 & 6.015 & 7.741 & 6.355 & 7.322 & 6.632 \\
\hline $\mathrm{N}$ & $2,166,627$ & 36,075 & 283,277 & 456,785 & 536,148 & 854,342 \\
\hline
\end{tabular}

**Significant at $1 \%$ level * at $5 \%$ level

Notes: Unweighted negative binomial estimates for the number of days the respondent engaged in vigorous activities and unweighted OLS estimates for the number of drinks are obtained using data from the 1990 to 2013 Behavioral Risk Factor Surveillance System. All regressions include state fixed effects, year fixed effects and state specific linear time trends. Demographic controls include gender, race/ethnicity, age (linear and quadratic), education, and marital status. State level policy and economic controls include marijuana decriminalization laws, state level alcohol and cigarette taxes, minimum wages, and per capita GDP. Standard errors corrected for clustering on the state are in parentheses. 
Table 10. Heterogeneity in the Effects of MMLs on Log of Wages

\begin{tabular}{|c|c|c|c|c|c|c|}
\hline & $\begin{array}{c}\text { All } \\
\text { Ages }\end{array}$ & $\begin{array}{c}\text { Ages } \\
\text { 18-to-19 }\end{array}$ & $\begin{array}{c}\text { Ages } \\
20-\text { to- } 29 \\
\end{array}$ & $\begin{array}{c}\text { Ages } \\
\text { 30-to-39 } \\
\end{array}$ & $\begin{array}{c}\text { Ages } \\
40-\text { to- } 49 \\
\end{array}$ & $\begin{array}{c}\text { Ages } \\
50-\text { to-64 } \\
\end{array}$ \\
\hline & \multicolumn{6}{|c|}{ Panel I: Collective Cultivation } \\
\hline Pooled & $\begin{array}{c}-0.024 * * \\
(0.008)\end{array}$ & $\begin{array}{l}-0.022^{*} \\
(0.011)\end{array}$ & $\begin{array}{c}-0.039 * * \\
(0.012)\end{array}$ & $\begin{array}{c}-0.030^{* *} \\
(0.011)\end{array}$ & $\begin{array}{c}-0.012 \\
(0.007)\end{array}$ & $\begin{array}{l}-0.016^{*} \\
(0.007)\end{array}$ \\
\hline $\mathrm{N}$ & $3,830,355$ & 114,498 & 851,953 & 997,335 & 983,448 & 883,121 \\
\hline Males & $\begin{array}{c}-0.025^{*} \\
(0.010)\end{array}$ & $\begin{array}{l}-0.020 \\
(0.011)\end{array}$ & $\begin{array}{c}-0.050 * * \\
(0.017)\end{array}$ & $\begin{array}{c}-0.033 * * \\
(0.010)\end{array}$ & $\begin{array}{l}-0.008 \\
(0.006)\end{array}$ & $\begin{array}{c}-0.007 \\
(0.011)\end{array}$ \\
\hline $\mathrm{N}$ & $1,938,600$ & 57,158 & 436,154 & 516,955 & 489,409 & 438,924 \\
\hline $\begin{array}{l}\text { Females } \\
* * \\
\mathrm{~N}\end{array}$ & $\begin{array}{c}-0.025 * * \\
(0.007) \\
1,891,755\end{array}$ & $\begin{array}{c}-0.024 \\
(0.014) \\
57,340 \\
\end{array}$ & $\begin{array}{c}-0.026 * * \\
(0.008) \\
415,799 \\
\end{array}$ & $\begin{array}{c}-0.029 * \\
(0.012) \\
480,380\end{array}$ & $\begin{array}{c}-0.017 \\
(0.011) \\
494,039\end{array}$ & $\begin{array}{c}-0.025 * * \\
(0.005) \\
444,197\end{array}$ \\
\hline $\mathrm{N}$ & \multicolumn{6}{|c|}{ Panel II: Home Cultivation } \\
\hline Pooled & $\begin{array}{c}-0.015 \\
(0.010) \\
3,830,355\end{array}$ & $\begin{array}{c}-0.017 \\
(0.010) \\
114,498\end{array}$ & $\begin{array}{c}-0.027 \\
(0.014) \\
851,953\end{array}$ & $\begin{array}{c}-0.017 \\
(0.014) \\
997,335\end{array}$ & $\begin{array}{c}-0.009 \\
(0.007) \\
983,448\end{array}$ & $\begin{array}{c}-0.010 \\
(0.007) \\
883,121\end{array}$ \\
\hline Males & $\begin{array}{c}-0.017 \\
(0.010) \\
1,938,600\end{array}$ & $\begin{array}{c}-0.015 \\
(0.010) \\
57,158\end{array}$ & $\begin{array}{c}-0.037^{*} \\
(0.018) \\
436,154\end{array}$ & $\begin{array}{c}-0.022 \\
(0.013) \\
516,955\end{array}$ & $\begin{array}{c}-0.004 \\
(0.006) \\
489,409\end{array}$ & $\begin{array}{c}-0.007 \\
(0.010) \\
438,924\end{array}$ \\
\hline Females & $\begin{array}{c}-0.013 \\
(0.009) \\
1,891,755\end{array}$ & $\begin{array}{c}-0.016 \\
(0.014) \\
57,340\end{array}$ & $\begin{array}{c}-0.015 \\
(0.010) \\
415,799\end{array}$ & $\begin{array}{c}-0.013 \\
(0.016) \\
480,380\end{array}$ & $\begin{array}{c}-0.015 \\
(0.011) \\
494,039\end{array}$ & $\begin{array}{c}-0.012 \\
(0.008) \\
444,197\end{array}$ \\
\hline $\mathrm{N}$ & \multicolumn{6}{|c|}{ Panel III: Pain } \\
\hline Pooled & $\begin{array}{c}-0.015 \\
(0.011) \\
3,830,355\end{array}$ & $\begin{array}{c}0.000 \\
(0.019) \\
114,498\end{array}$ & $\begin{array}{c}-0.027^{*} \\
(0.013) \\
851,953\end{array}$ & $\begin{array}{c}-0.022 \\
(0.013) \\
997,335\end{array}$ & $\begin{array}{c}-0.006 \\
(0.008) \\
983,448\end{array}$ & $\begin{array}{c}-0.008 \\
(0.008) \\
883,121\end{array}$ \\
\hline Males & $\begin{array}{l}-0.019 \\
(0.013)\end{array}$ & $\begin{array}{l}-0.009 \\
(0.016)\end{array}$ & $\begin{array}{c}-0.038^{*} \\
(0.017)\end{array}$ & $\begin{array}{l}-0.026 \\
(0.013)\end{array}$ & $\begin{array}{c}-0.008 \\
(0.008)\end{array}$ & $\begin{array}{c}-0.003 \\
(0.011)\end{array}$ \\
\hline $\mathrm{N}$ & $1,938,600$ & 57,158 & 436,154 & 516,955 & 489,409 & 438,924 \\
\hline Females & $\begin{array}{l}-0.013 \\
(0.009)\end{array}$ & $\begin{array}{c}0.011 \\
(0.022)\end{array}$ & $\begin{array}{l}-0.015 \\
(0.009)\end{array}$ & $\begin{array}{l}-0.018 \\
(0.013)\end{array}$ & $\begin{array}{l}-0.006 \\
(0.008)\end{array}$ & $\begin{array}{c}-0.013^{*} \\
(0.006)\end{array}$ \\
\hline $\mathrm{N}$ & $1,891,755$ & 57,340 & 415,799 & 480,380 & 494,039 & 444,197 \\
\hline
\end{tabular}

**Significant at $1 \%$ level $*$ at $5 \%$ level

Notes: Weighted OLS estimates are obtained using data from the 1990 to 2014 Current Population Survey Outgoing

Rotation Groups. Each coefficient represents a result from separate weighted regressions that include state fixed

effects, year fixed effects and state specific time trends. All regressions include state fixed effects, year fixed effects and state specific linear time trends. Demographic controls include gender, race/ethnicity, potential experience (linear and squared), education, marital status, and industry classification. State level policy and economic controls include marijuana decriminalization laws, state level alcohol and cigarette taxes, minimum wages, and per capita GDP. Standard errors corrected for clustering on the state are in parentheses. 


\section{Appendix Table 1. Robustness of Estimates with the Use of Alternative MML Effective Dates to Indicate Whether a State Has an Effective MML in the Entire Year}

\begin{tabular}{|c|c|c|c|c|c|c|}
\hline & $\begin{array}{c}\text { All } \\
\text { Ages }\end{array}$ & $\begin{array}{c}\text { Ages } \\
\text { 18-to-19 }\end{array}$ & $\begin{array}{c}\text { Ages } \\
\text { 20-to-29 }\end{array}$ & $\begin{array}{c}\text { Ages } \\
\text { 30-to-39 }\end{array}$ & $\begin{array}{c}\text { Ages } \\
40-\text { to- } 49\end{array}$ & $\begin{array}{c}\text { Ages } \\
50-\text { to-64 }\end{array}$ \\
\hline & \multicolumn{6}{|c|}{ Panel I: Pooled Sample } \\
\hline Employment & $\begin{array}{c}0.002 \\
(0.003)\end{array}$ & $\begin{array}{c}0.005 \\
(0.007)\end{array}$ & $\begin{array}{l}0.006^{*} \\
(0.003)\end{array}$ & $\begin{array}{c}0.002 \\
(0.004)\end{array}$ & $\begin{array}{c}0.003 \\
(0.004)\end{array}$ & $\begin{array}{c}-0.003 \\
(0.005)\end{array}$ \\
\hline $\mathrm{N}$ & $6,189,607$ & 260,249 & $1,289,255$ & $1,464,569$ & $1,480,498$ & $1,695,036$ \\
\hline Hours & $\begin{array}{c}0.001 \\
(0.002)\end{array}$ & $\begin{array}{c}0.018 \\
(0.010)\end{array}$ & $\begin{array}{c}0.004 \\
(0.003)\end{array}$ & $\begin{array}{l}-0.001 \\
(0.002)\end{array}$ & $\begin{array}{c}0.001 \\
(0.003)\end{array}$ & $\begin{array}{c}-0.002 \\
(0.002)\end{array}$ \\
\hline $\mathrm{N}$ & $3,830,355$ & 114,498 & 851,953 & 997,335 & 983,448 & 883,121 \\
\hline Wages & $\begin{array}{c}-0.012 \\
(0.007) \\
3830355\end{array}$ & $\begin{array}{l}-0.006 \\
(0.011) \\
114498\end{array}$ & $\begin{array}{c}-0.018 \\
(0.012) \\
851953\end{array}$ & $\begin{array}{c}-0.015 \\
(0.011) \\
997335\end{array}$ & $\begin{array}{c}-0.007 \\
(0.005) \\
983448\end{array}$ & $\begin{array}{c}-0.009 * \\
(0.005) \\
883121\end{array}$ \\
\hline $\mathrm{N}$ & \multicolumn{6}{|c|}{ Panel II: Males } \\
\hline Employment & $\begin{array}{c}0.002 \\
(0.004)\end{array}$ & $\begin{array}{c}0.009 \\
(0.010)\end{array}$ & $\begin{array}{c}0.005 \\
(0.005)\end{array}$ & $\begin{array}{c}0.003 \\
(0.005)\end{array}$ & $\begin{array}{c}0.007 \\
(0.004)\end{array}$ & $\begin{array}{l}-0.005 \\
(0.005)\end{array}$ \\
\hline $\mathrm{N}$ & $2,979,660$ & 130,858 & 621,919 & 700,506 & 713,095 & 813,282 \\
\hline Hours & $\begin{array}{l}-0.000 \\
(0.003)\end{array}$ & $\begin{array}{c}0.013 \\
(0.018)\end{array}$ & $\begin{array}{c}0.001 \\
(0.003)\end{array}$ & $\begin{array}{l}-0.004 \\
(0.003)\end{array}$ & $\begin{array}{l}-0.001 \\
(0.003)\end{array}$ & $\begin{array}{c}0.001 \\
(0.003)\end{array}$ \\
\hline $\mathrm{N}$ & $1,938,600$ & 57,158 & 436,154 & 516,955 & 489,409 & 438,924 \\
\hline Wages & $\begin{array}{l}-0.013 \\
(0.009)\end{array}$ & $\begin{array}{l}-0.011 \\
(0.009)\end{array}$ & $\begin{array}{c}-0.028 \\
(0.015)\end{array}$ & $\begin{array}{l}-0.013 \\
(0.009)\end{array}$ & $\begin{array}{l}-0.011 \\
(0.009)\end{array}$ & $\begin{array}{l}-0.028 \\
(0.015)\end{array}$ \\
\hline \multirow[t]{2}{*}{$\mathrm{N}$} & -0.013 & -0.011 & -0.028 & -0.013 & -0.011 & -0.028 \\
\hline & \multicolumn{6}{|c|}{ Panel III: Females } \\
\hline Employment & $\begin{array}{c}0.002 \\
(0.004)\end{array}$ & $\begin{array}{c}0.003 \\
(0.010)\end{array}$ & $\begin{array}{c}0.008 \\
(0.005)\end{array}$ & $\begin{array}{l}-0.000 \\
(0.004)\end{array}$ & $\begin{array}{c}-0.002 \\
(0.004)\end{array}$ & $\begin{array}{l}-0.000 \\
(0.007)\end{array}$ \\
\hline $\mathrm{N}$ & $3,209,947$ & 129,391 & 667,336 & 764,063 & 767,403 & 881,754 \\
\hline Hours & $\begin{array}{c}0.003 \\
(0.002)\end{array}$ & $\begin{array}{c}0.023 \\
(0.020)\end{array}$ & $\begin{array}{c}0.006 \\
(0.004)\end{array}$ & $\begin{array}{c}0.001 \\
(0.003)\end{array}$ & $\begin{array}{c}0.002 \\
(0.004)\end{array}$ & $\begin{array}{l}-0.006 \\
(0.004)\end{array}$ \\
\hline $\mathrm{N}$ & $1,891,755$ & 57,340 & 415,799 & 480,380 & 494,039 & 444,197 \\
\hline Wages & $\begin{array}{c}-0.011 \\
(0.006)\end{array}$ & $\begin{array}{l}-0.000 \\
(0.014)\end{array}$ & $\begin{array}{l}-0.008 \\
(0.009)\end{array}$ & $\begin{array}{l}-0.012 \\
(0.012)\end{array}$ & $\begin{array}{l}-0.012 \\
(0.007)\end{array}$ & $\begin{array}{c}-0.013 * \\
(0.005)\end{array}$ \\
\hline $\mathrm{N}$ & $1,891,755$ & 57,340 & 415,799 & 480,380 & 494,039 & 444,197 \\
\hline
\end{tabular}

**Significant at $1 \%$ level * at $5 \%$ level

Notes: Weighted OLS estimates are obtained using data from the 1990 to 2014 Current Population Survey Outgoing Rotation Groups. All regressions include state fixed effects, year fixed effects and state specific linear time trends. Demographic controls include gender, race/ethnicity, age (linear and squared)/potential experience (linear and squared), education, marital status, industry classification, and whether the respondent enrolls in school. State level policy and economic controls include marijuana decriminalization laws, state level alcohol and cigarette taxes, minimum wages, and per capita GDP. Standard errors corrected for clustering on the state are in parentheses. 
Appendix Table 2. Robustness of Estimates with the Use of Alternative MML Effective Dates to Indicate Whether a State Has an Effective MML at Any Time in a Given Year

\begin{tabular}{|c|c|c|c|c|c|c|}
\hline & $\begin{array}{c}\text { All } \\
\text { Ages }\end{array}$ & $\begin{array}{c}\text { Ages } \\
\text { 18-to-19 }\end{array}$ & $\begin{array}{c}\text { Ages } \\
\text { 20-to-29 }\end{array}$ & $\begin{array}{c}\text { Ages } \\
\text { 30-to-39 }\end{array}$ & $\begin{array}{c}\text { Ages } \\
40-\text { to- } 49\end{array}$ & $\begin{array}{c}\text { Ages } \\
50-\text { to-64 }\end{array}$ \\
\hline & \multicolumn{6}{|c|}{ Panel I: Pooled Sample } \\
\hline Employment & $\begin{array}{c}-0.000 \\
(0.004)\end{array}$ & $\begin{array}{l}-0.000 \\
(0.007)\end{array}$ & $\begin{array}{c}0.002 \\
(0.005)\end{array}$ & $\begin{array}{c}-0.001 \\
(0.004)\end{array}$ & $\begin{array}{c}0.002 \\
(0.004)\end{array}$ & $\begin{array}{c}-0.004 \\
(0.004)\end{array}$ \\
\hline $\mathrm{N}$ & $6,189,607$ & 260,249 & $1,289,255$ & $1,464,569$ & $1,480,498$ & $1,695,036$ \\
\hline Hours & $\begin{array}{c}0.000 \\
(0.002)\end{array}$ & $\begin{array}{c}0.013 \\
(0.010)\end{array}$ & $\begin{array}{c}0.000 \\
(0.003)\end{array}$ & $\begin{array}{l}-0.000 \\
(0.002)\end{array}$ & $\begin{array}{l}-0.001 \\
(0.002)\end{array}$ & $\begin{array}{c}-0.001 \\
(0.002)\end{array}$ \\
\hline $\mathrm{N}$ & $3,830,355$ & 114,498 & 851,953 & 997,335 & 983,448 & 883,121 \\
\hline Wages & $\begin{array}{l}-0.011 \\
(0.009)\end{array}$ & $\begin{array}{l}-0.007 \\
(0.014)\end{array}$ & $\begin{array}{l}-0.021 * \\
(0.010)\end{array}$ & $\begin{array}{c}-0.013 \\
(0.012) \\
007335\end{array}$ & $\begin{array}{c}-0.008 \\
(0.007) \\
083448\end{array}$ & $\begin{array}{l}-0.002 \\
(0.007) \\
883121\end{array}$ \\
\hline $\mathrm{N}$ & \multicolumn{6}{|c|}{ Panel II: Males } \\
\hline Employment & $\begin{array}{c}0.002 \\
(0.004)\end{array}$ & $\begin{array}{c}0.007 \\
(0.007)\end{array}$ & $\begin{array}{c}0.003 \\
(0.006)\end{array}$ & $\begin{array}{c}0.004 \\
(0.005)\end{array}$ & $\begin{array}{c}0.006 \\
(0.006)\end{array}$ & $\begin{array}{c}-0.004 \\
(0.004)\end{array}$ \\
\hline $\mathrm{N}$ & $2,979,660$ & 130,858 & 621,919 & 700,506 & 713,095 & 813,282 \\
\hline Hours & $\begin{array}{l}-0.001 \\
(0.002)\end{array}$ & $\begin{array}{c}0.014 \\
(0.016)\end{array}$ & $\begin{array}{l}-0.002 \\
(0.003)\end{array}$ & $\begin{array}{l}-0.003 \\
(0.002)\end{array}$ & $\begin{array}{l}-0.003 \\
(0.002)\end{array}$ & $\begin{array}{c}0.002 \\
(0.002)\end{array}$ \\
\hline $\mathrm{N}$ & $1,938,600$ & 57,158 & 436,154 & 516,955 & 489,409 & 438,924 \\
\hline Wages & $\begin{array}{l}-0.014 \\
(0.010)\end{array}$ & $\begin{array}{l}-0.009 \\
(0.013)\end{array}$ & $\begin{array}{c}-0.030^{*} \\
(0.013)\end{array}$ & $\begin{array}{l}-0.020 \\
(0.011)\end{array}$ & $\begin{array}{l}-0.005 \\
(0.008)\end{array}$ & $\begin{array}{c}0.001 \\
(0.009)\end{array}$ \\
\hline \multirow[t]{2}{*}{$\mathrm{N}$} & $1,938,600$ & 57,158 & 436,154 & 516,955 & 489,409 & 438,924 \\
\hline & \multicolumn{6}{|c|}{ Panel III: Females } \\
\hline Employment & $\begin{array}{c}-0.002 \\
(0.004) \\
3,209,947\end{array}$ & $\begin{array}{c}-0.006 \\
(0.012) \\
129,391\end{array}$ & $\begin{array}{c}0.001 \\
(0.006) \\
667,336\end{array}$ & $\begin{array}{c}-0.006 \\
(0.005) \\
764,063\end{array}$ & $\begin{array}{c}-0.001 \\
(0.004) \\
767,403\end{array}$ & $\begin{array}{c}-0.004 \\
(0.006) \\
881,754\end{array}$ \\
\hline Hours & $\begin{array}{c}0.002 \\
(0.002)\end{array}$ & $\begin{array}{c}0.013 \\
(0.021)\end{array}$ & $\begin{array}{c}0.003 \\
(0.004)\end{array}$ & $\begin{array}{c}0.003 \\
(0.003)\end{array}$ & $\begin{array}{c}-0.001 \\
(0.004)\end{array}$ & $\begin{array}{c}-0.004 \\
(0.003)\end{array}$ \\
\hline $\mathrm{N}$ & $1,891,755$ & 57,340 & 415,799 & 480,380 & 494,039 & 444,197 \\
\hline Wages & $\begin{array}{c}-0.008 \\
(0.008)\end{array}$ & $\begin{array}{l}-0.003 \\
(0.017)\end{array}$ & $\begin{array}{c}-0.011 \\
(0.007)\end{array}$ & $\begin{array}{c}-0.006 \\
(0.013)\end{array}$ & $\begin{array}{c}-0.012 \\
(0.009)\end{array}$ & $\begin{array}{l}-0.005 \\
(0.007)\end{array}$ \\
\hline $\mathrm{N}$ & $1,891,755$ & 57,340 & 415,799 & 480,380 & 494,039 & 444,197 \\
\hline
\end{tabular}

**Significant at $1 \%$ level $*$ at $5 \%$ level

Notes: Weighted OLS estimates are obtained using data from the 1990 to 2014 Current Population Survey Outgoing Rotation Groups. All regressions include state fixed effects, year fixed effects and state specific linear time trends. Demographic controls include gender, race/ethnicity, age (linear and squared)/potential experience (linear and squared), education, marital status, industry classification, and whether the respondent enrolls in school. State level policy and economic controls include marijuana decriminalization laws, state level alcohol and cigarette taxes, minimum wages, and per capita GDP. Standard errors corrected for clustering on the state are in parentheses. 
Appendix Table 3. State Medical Marijuana Laws by Specific Provisions

\begin{tabular}{|c|c|c|c|}
\hline \multirow[b]{2}{*}{ State } & \multicolumn{3}{|c|}{ Provisions } \\
\hline & $\begin{array}{c}\text { Collective } \\
\text { Cultivation }\end{array}$ & $\begin{array}{c}\text { Home } \\
\text { Cultivation }\end{array}$ & Pain \\
\hline Alaska & & Yes & Yes \\
\hline Arizona & Yes & Yes & Yes \\
\hline California & Yes & Yes & Yes \\
\hline Colorado & Yes & Yes & Yes \\
\hline \multicolumn{4}{|l|}{ Connecticut } \\
\hline Delaware & & & Yes \\
\hline \multicolumn{4}{|c|}{ Washington, D.C. } \\
\hline Hawaii & & Yes & Yes \\
\hline \multicolumn{4}{|l|}{ Illinois } \\
\hline Maine & & Yes & Yes \\
\hline Maryland & & & Yes \\
\hline Massachusetts & Yes & Yes & \\
\hline Michigan & & & Yes \\
\hline \multicolumn{4}{|l|}{ Minnesota } \\
\hline Montana & Yes & Yes & Yes \\
\hline Nevada & Yes & Yes & Yes \\
\hline \multicolumn{4}{|c|}{ New Hampshire } \\
\hline New Jersey & & & Yes \\
\hline New Mexico & & Yes & \\
\hline \multicolumn{4}{|l|}{ New York } \\
\hline Oregon & Yes & Yes & Yes \\
\hline Rhode Island & Yes & Yes & Yes \\
\hline Vermont & & Yes & Yes \\
\hline Washington & Yes & Yes & Yes \\
\hline
\end{tabular}




\section{Appendix Table 4. Robustness of Estimates of the Effect of MMLs with the Alternative Definition of Employment}

\begin{tabular}{lcccccc}
\hline & All & Ages & Ages & Ages & Ages & Ages \\
& Ages & $\mathbf{1 8 - t o - 1 9}$ & $\mathbf{2 0 - t o - 2 9}$ & $\mathbf{3 0 - t o - 3 9}$ & $\mathbf{4 0 - t o - 4 9}$ & $\mathbf{5 0 - t o - 6 4}$ \\
\hline Pooled & \multicolumn{7}{c}{ Panel I: Baseline difference-in-difference estimates } \\
& 0.003 & -0.011 & 0.000 & 0.002 & $0.004^{*}$ & 0.006 \\
$\mathrm{~N}$ & $(0.002)$ & $(0.009)$ & $(0.004)$ & $(0.002)$ & $(0.002)$ & $(0.004)$ \\
Males & $6,189,607$ & 260,249 & $1,289,255$ & $1,464,569$ & $1,480,498$ & $1,695,036$ \\
& 0.003 & -0.012 & -0.003 & 0.001 & $0.008^{* *}$ & 0.010 \\
& $(0.002)$ & $(0.013)$ & $(0.004)$ & $(0.003)$ & $(0.002)$ & $(0.006)$ \\
Females & $2,979,660$ & 130,858 & 621,919 & 700,506 & 713,095 & 813,282 \\
& 0.003 & -0.009 & 0.003 & 0.003 & -0.001 & 0.002 \\
$\mathrm{~N}$ & $(0.003)$ & $(0.007)$ & $(0.005)$ & $(0.004)$ & $(0.002)$ & $(0.004)$ \\
& $3,209,947$ & 129,391 & 667,336 & 764,063 & 767,403 & 881,754 \\
\hline
\end{tabular}

Panel II: Difference-in-difference estimates with state-specific linear

\begin{tabular}{lcccccc}
\multicolumn{7}{c}{ time trends } \\
Pooled & 0.001 & 0.006 & 0.004 & -0.002 & 0.001 & 0.001 \\
$\mathrm{~N}$ & $(0.002)$ & $(0.006)$ & $(0.002)$ & $(0.002)$ & $(0.002)$ & $(0.004)$ \\
Males & $6,189,607$ & 260,249 & $1,289,255$ & $1,464,569$ & $1,480,498$ & $1,695,036$ \\
& 0.002 & 0.011 & 0.003 & -0.003 & 0.005 & 0.005 \\
$\mathrm{~N}$ & $(0.002)$ & $(0.010)$ & $(0.003)$ & $(0.003)$ & $(0.002)$ & $(0.004)$ \\
Females & $2,979,660$ & 130,858 & 621,919 & 700,506 & 713,095 & 813,282 \\
& 0.000 & 0.004 & 0.004 & -0.002 & -0.004 & -0.002 \\
$\mathrm{~N}$ & $(0.003)$ & $(0.007)$ & $(0.004)$ & $(0.004)$ & $(0.002)$ & $(0.005)$ \\
& $3,209,947$ & 129,391 & 667,336 & 764,063 & 767,403 & 881,754 \\
\hline
\end{tabular}

**Significant at $1 \%$ level * at $5 \%$ level

Notes: Weighted OLS estimates are obtained using data from the 1990 to 2014 Current Population Survey Outgoing Rotation Groups. All regressions include state fixed effects and year fixed effects. Demographic controls include gender, race/ethnicity, age (linear and squared), education, marital status, and whether the respondent enrolls in school. State level policy and economic controls include marijuana decriminalization laws, state level alcohol and cigarette taxes, minimum wages, and per capita GDP. Standard errors corrected for clustering on the state are in parentheses. 
Appendix Table 5. Robustness of Log Wage Estimates to Correct for Selection Bias Using the Heckman Model

\begin{tabular}{lcccccc}
\hline & All & Ages & Ages & Ages & Ages & Ages \\
& Ages & $\mathbf{1 8 - t o - 1 9}$ & $\mathbf{2 0 - t o - 2 9}$ & $\mathbf{3 0 - t o - 3 9}$ & $\mathbf{4 0 - t 0 - 4 9}$ & $\mathbf{5 0 - t o - 6 4}$ \\
\hline Pooled & -0.011 & -0.003 & -0.015 & -0.012 & -0.006 & -0.005 \\
& $(0.008)$ & $(0.011)$ & $(0.010)$ & $(0.011)$ & $(0.006)$ & $(0.006)$ \\
$\mathrm{N}$ & $6,101,945$ & 259,153 & $1,276,013$ & $1,443,124$ & $1,455,536$ & $1,668,119$ \\
\multirow{2}{*}{ Males } & -0.012 & 0.001 & $-0.024 *$ & -0.015 & 0.001 & -0.000 \\
& $(0.009)$ & $(0.011)$ & $(0.011)$ & $(0.012)$ & $(0.005)$ & $(0.006)$ \\
$\mathrm{N}$ & $2,926,099$ & 130,191 & 613,767 & 687,168 & 697,912 & 797,061 \\
\multirow{2}{*}{ Females } & -0.010 & -0.004 & -0.006 & -0.010 & -0.014 & -0.010 \\
& $(0.006)$ & $(0.013)$ & $(0.009)$ & $(0.011)$ & $(0.008)$ & $(0.007)$ \\
$\mathrm{N}$ & $3,175,846$ & 128,962 & 662,246 & 755,956 & 757,624 & 871,058 \\
\hline
\end{tabular}

**Significant at $1 \%$ level $*$ at $5 \%$ level

Notes: Weighted OLS estimates are obtained using data from the 1990 to 2014 Current Population Survey Outgoing Rotation Groups. All regressions include state fixed effects, year fixed effects and state specific linear time trends. Demographic controls include gender, race/ethnicity, age (linear and squared)/potential experience (linear and squared), education, marital status, industry classification, and whether the respondent enrolls in school. State level policy and economic controls include marijuana decriminalization laws, state level alcohol and cigarette taxes, minimum wages, and per capita GDP. Standard errors corrected for clustering on the state are in parentheses. 
Appendix Table 6. Robustness of Estimates with the Use of MML Effective Dates Preferred by Powell et al.'s (2015)

\begin{tabular}{|c|c|c|c|c|c|c|}
\hline & $\begin{array}{c}\text { All } \\
\text { Ages }\end{array}$ & $\begin{array}{c}\text { Ages } \\
\text { 18-to-19 }\end{array}$ & $\begin{array}{c}\text { Ages } \\
\text { 20-to-29 }\end{array}$ & $\begin{array}{c}\text { Ages } \\
\text { 30-to-39 }\end{array}$ & $\begin{array}{c}\text { Ages } \\
40-\text { to- } 49\end{array}$ & $\begin{array}{c}\text { Ages } \\
50-\text { to-64 }\end{array}$ \\
\hline & \multicolumn{6}{|c|}{ Panel I: Pooled Sample } \\
\hline Employment & $\begin{array}{c}0.002 \\
(0.003)\end{array}$ & $\begin{array}{c}0.004 \\
(0.006)\end{array}$ & $\begin{array}{l}0.006^{*} \\
(0.003)\end{array}$ & $\begin{array}{c}0.001 \\
(0.004)\end{array}$ & $\begin{array}{c}0.002 \\
(0.003)\end{array}$ & $\begin{array}{c}-0.003 \\
(0.004)\end{array}$ \\
\hline $\mathrm{N}$ & $6,189,607$ & 260,249 & $1,289,255$ & $1,464,569$ & $1,480,498$ & $1,695,036$ \\
\hline Hours & $\begin{array}{c}0.001 \\
(0.002)\end{array}$ & $\begin{array}{l}0.019^{*} \\
(0.009)\end{array}$ & $\begin{array}{c}0.003 \\
(0.003)\end{array}$ & $\begin{array}{l}-0.001 \\
(0.002)\end{array}$ & $\begin{array}{c}0.001 \\
(0.002)\end{array}$ & $\begin{array}{l}-0.002 \\
(0.002)\end{array}$ \\
\hline $\mathrm{N}$ & $3,830,355$ & 114,498 & 851,953 & 997,335 & 983,448 & 883,121 \\
\hline Wages & $\begin{array}{c}-0.009 \\
(0.007)\end{array}$ & $\begin{array}{l}-0.005 \\
(0.011) \\
114498\end{array}$ & $\begin{array}{c}-0.018 \\
(0.011) \\
851953\end{array}$ & $\begin{array}{c}-0.010 \\
(0.012) \\
997335\end{array}$ & $\begin{array}{c}-0.006 \\
(0.006) \\
983448\end{array}$ & $\begin{array}{c}-0.007 \\
(0.005) \\
883121\end{array}$ \\
\hline $\mathrm{N}$ & \multicolumn{6}{|c|}{ Panel II: Males } \\
\hline Employment & $\begin{array}{c}0.003 \\
(0.004)\end{array}$ & $\begin{array}{c}0.011 \\
(0.009)\end{array}$ & $\begin{array}{c}0.005 \\
(0.005)\end{array}$ & $\begin{array}{c}0.004 \\
(0.005)\end{array}$ & $\begin{array}{c}0.007 \\
(0.004)\end{array}$ & $\begin{array}{c}-0.002 \\
(0.004)\end{array}$ \\
\hline $\mathrm{N}$ & $2,979,660$ & 130,858 & 621,919 & 700,506 & 713,095 & 813,282 \\
\hline Hours & $\begin{array}{c}-0.000 \\
(0.002)\end{array}$ & $\begin{array}{c}0.016 \\
(0.017)\end{array}$ & $\begin{array}{c}0.002 \\
(0.003)\end{array}$ & $\begin{array}{c}-0.004 \\
(0.003)\end{array}$ & $\begin{array}{l}-0.001 \\
(0.002)\end{array}$ & $\begin{array}{c}0.001 \\
(0.002)\end{array}$ \\
\hline $\mathrm{N}$ & $1,938,600$ & 57,158 & 436,154 & 516,955 & 489,409 & 438,924 \\
\hline Wages & $\begin{array}{c}-0.010 \\
(0.008)\end{array}$ & $\begin{array}{l}-0.008 \\
(0.010)\end{array}$ & $\begin{array}{l}-0.027 * \\
(0.012)\end{array}$ & $\begin{array}{l}-0.013 \\
(0.012)\end{array}$ & $\begin{array}{c}0.001 \\
(0.005)\end{array}$ & $\begin{array}{l}-0.003 \\
(0.005)\end{array}$ \\
\hline \multirow[t]{2}{*}{$\mathrm{N}$} & $1,938,600$ & 57,158 & 436,154 & 516,955 & 489,409 & 438,924 \\
\hline & \multicolumn{6}{|c|}{ Panel III: Females } \\
\hline Employment & $\begin{array}{c}0.001 \\
(0.004)\end{array}$ & $\begin{array}{c}0.000 \\
(0.010)\end{array}$ & $\begin{array}{c}0.007 \\
(0.004)\end{array}$ & $\begin{array}{c}-0.002 \\
(0.005)\end{array}$ & $\begin{array}{l}-0.003 \\
(0.004)\end{array}$ & $\begin{array}{c}-0.002 \\
(0.006) \\
881754\end{array}$ \\
\hline Hours & $\begin{array}{c}0.002 \\
(0.002)\end{array}$ & $\begin{array}{c}0.022 \\
(0.022)\end{array}$ & $\begin{array}{c}0.002 \\
(0.004)\end{array}$ & $\begin{array}{c}0.002 \\
(0.003)\end{array}$ & $\begin{array}{c}0.002 \\
(0.004)\end{array}$ & $\begin{array}{c}-0.004 \\
(0.003)\end{array}$ \\
\hline $\mathrm{N}$ & $1,891,755$ & 57,340 & 415,799 & 480,380 & 494,039 & 444,197 \\
\hline Wages & $\begin{array}{l}-0.009 \\
(0.007)\end{array}$ & $\begin{array}{c}-0.002 \\
(0.014)\end{array}$ & $\begin{array}{l}-0.008 \\
(0.009)\end{array}$ & $\begin{array}{l}-0.007 \\
(0.012)\end{array}$ & $\begin{array}{l}-0.012 \\
(0.007)\end{array}$ & $\begin{array}{c}-0.011 \\
(0.006)\end{array}$ \\
\hline $\mathrm{N}$ & $1,891,755$ & 57,340 & 415,799 & 480,380 & 494,039 & 444,197 \\
\hline
\end{tabular}

**Significant at $1 \%$ level * at $5 \%$ level

Notes: Weighted OLS estimates are obtained using data from the 1990 to 2014 Current Population Survey Outgoing Rotation Groups. All regressions include state fixed effects, year fixed effects and state specific linear time trends. Demographic controls include gender, race/ethnicity, age (linear and squared)/potential experience (linear and squared), education, marital status, industry classification, and whether the respondent enrolls in school. State level policy and economic controls include marijuana decriminalization laws, state level alcohol and cigarette taxes, minimum wages, and per capita GDP. Standard errors corrected for clustering on the state are in parentheses. 
Appendix Table 7. Robustness of Estimates the Effect of MMLs on Employment to Control for Policy Leads and Lags

\begin{tabular}{|c|c|c|c|c|c|c|}
\hline & $\begin{array}{c}\text { All } \\
\text { Ages }\end{array}$ & $\begin{array}{c}\text { Ages } \\
\text { 18-to-19 } \\
\end{array}$ & $\begin{array}{c}\text { Ages } \\
\text { 20-to-29 }\end{array}$ & $\begin{array}{c}\text { Ages } \\
\text { 30-to-39 }\end{array}$ & $\begin{array}{c}\text { Ages } \\
\text { 40-to-49 } \\
\end{array}$ & $\begin{array}{c}\text { Ages } \\
50-\text { to-64 } \\
\end{array}$ \\
\hline & \multicolumn{6}{|c|}{ Panel I: Pooled Sample } \\
\hline 4 Years Prior & $\begin{array}{c}0.001 \\
(0.003)\end{array}$ & $\begin{array}{c}0.007 \\
(0.006)\end{array}$ & $\begin{array}{c}0.004 \\
(0.004)\end{array}$ & $\begin{array}{c}-0.002 \\
(0.004)\end{array}$ & $\begin{array}{c}-0.002 \\
(0.003)\end{array}$ & $\begin{array}{c}0.002 \\
(0.004)\end{array}$ \\
\hline 3 Years Prior & $\begin{array}{c}0.001 \\
(0.002)\end{array}$ & $\begin{array}{l}-0.003 \\
(0.008)\end{array}$ & $\begin{array}{c}0.004 \\
(0.004)\end{array}$ & $\begin{array}{l}-0.002 \\
(0.005)\end{array}$ & $\begin{array}{l}-0.004 \\
(0.005)\end{array}$ & $\begin{array}{c}0.006 \\
(0.005)\end{array}$ \\
\hline 2 Years Prior & $\begin{array}{c}0.001 \\
(0.004)\end{array}$ & $\begin{array}{c}-0.002 \\
(0.009)\end{array}$ & $\begin{array}{c}0.000 \\
(0.005)\end{array}$ & $\begin{array}{c}0.001 \\
(0.003)\end{array}$ & $\begin{array}{c}0.006 \\
(0.007)\end{array}$ & $\begin{array}{c}0.000 \\
(0.004)\end{array}$ \\
\hline 1 Year Prior & $\begin{array}{l}-0.003 \\
(0.004)\end{array}$ & $\begin{array}{l}-0.003 \\
(0.011)\end{array}$ & $\begin{array}{l}-0.000 \\
(0.006)\end{array}$ & $\begin{array}{c}-0.002 \\
(0.005)\end{array}$ & $\begin{array}{c}0.004 \\
(0.005)\end{array}$ & $\begin{array}{l}-0.008 \\
(0.005)\end{array}$ \\
\hline Year of law changed & $\begin{array}{c}0.000 \\
(0.005)\end{array}$ & $\begin{array}{l}-0.008 \\
(0.007)\end{array}$ & $\begin{array}{c}0.007 \\
(0.007)\end{array}$ & $\begin{array}{l}-0.005 \\
(0.006)\end{array}$ & $\begin{array}{c}0.003 \\
(0.006)\end{array}$ & $\begin{array}{l}-0.002 \\
(0.006)\end{array}$ \\
\hline 1 Year After & $\begin{array}{c}0.002 \\
(0.005)\end{array}$ & $\begin{array}{c}0.000 \\
(0.010)\end{array}$ & $\begin{array}{c}0.005 \\
(0.005)\end{array}$ & $\begin{array}{c}0.002 \\
(0.008)\end{array}$ & $\begin{array}{c}0.006 \\
(0.006)\end{array}$ & $\begin{array}{c}-0.003 \\
(0.006)\end{array}$ \\
\hline 2 Years After & $\begin{array}{l}-0.000 \\
(0.005)\end{array}$ & $\begin{array}{c}0.015 \\
(0.010)\end{array}$ & $\begin{array}{c}0.004 \\
(0.005)\end{array}$ & $\begin{array}{c}0.000 \\
(0.006)\end{array}$ & $\begin{array}{l}-0.004 \\
(0.007)\end{array}$ & $\begin{array}{l}-0.004 \\
(0.006)\end{array}$ \\
\hline $3+$ Years After & $\begin{array}{c}0.005 \\
(0.006)\end{array}$ & $\begin{array}{c}0.016 \\
(0.011)\end{array}$ & $\begin{array}{l}0.013^{*} \\
(0.006)\end{array}$ & $\begin{array}{c}0.007 \\
(0.007)\end{array}$ & $\begin{array}{c}0.004 \\
(0.008)\end{array}$ & $\begin{array}{l}-0.003 \\
(0.005)\end{array}$ \\
\hline $\begin{array}{l}\chi^{2} \text { of } \sum\left(\beta_{\text {leads }}\right)=0 \\
\text {-value } \\
\chi^{2} \text { of } \sum\left(\beta_{\text {yrchange, }}, \beta_{\text {lags }}\right)=0 \\
\text { p-value }\end{array}$ & $\begin{array}{l}0.001 \\
0.976 \\
0.132 \\
0.718\end{array}$ & $\begin{array}{l}0.001 \\
0.979 \\
0.558 \\
0.459\end{array}$ & $\begin{array}{c}0.25 \\
0.619 \\
2.331 \\
0.133\end{array}$ & $\begin{array}{c}0.184 \\
0.67 \\
0.054 \\
0.818\end{array}$ & $\begin{array}{c}0.11 \\
0.742 \\
0.119 \\
0.731\end{array}$ & $\begin{array}{l}0.001 \\
0.977 \\
0.343 \\
0.561\end{array}$ \\
\hline \multirow[t]{2}{*}{$\mathrm{N}$} & $6,189,607$ & 260,249 & $1,289,255$ & $1,464,569$ & $1,480,498$ & $1,695,036$ \\
\hline & \multicolumn{6}{|c|}{ Panel II: Males } \\
\hline 4 Years Prior & $\begin{array}{c}0.002 \\
(0.003)\end{array}$ & $\begin{array}{c}0.014 \\
(0.009)\end{array}$ & $\begin{array}{c}0.005 \\
(0.006)\end{array}$ & $\begin{array}{c}0.001 \\
(0.005)\end{array}$ & $\begin{array}{c}0.005 \\
(0.003)\end{array}$ & $\begin{array}{c}-0.002 \\
(0.005)\end{array}$ \\
\hline 3 Years Prior & $\begin{array}{c}0.005 \\
(0.003)\end{array}$ & $\begin{array}{c}-0.018^{*} \\
(0.009)\end{array}$ & $\begin{array}{c}0.006 \\
(0.006)\end{array}$ & $\begin{array}{c}0.003 \\
(0.006)\end{array}$ & $\begin{array}{c}0.006 \\
(0.007)\end{array}$ & $\begin{array}{c}0.009 \\
(0.006)\end{array}$ \\
\hline 2 Years Prior & $\begin{array}{c}0.003 \\
(0.004)\end{array}$ & $\begin{array}{l}-0.008 \\
(0.012)\end{array}$ & $\begin{array}{c}0.006 \\
(0.007)\end{array}$ & $\begin{array}{l}0.009^{*} \\
(0.003)\end{array}$ & $\begin{array}{c}0.009 \\
(0.008)\end{array}$ & $\begin{array}{l}-0.002 \\
(0.005)\end{array}$ \\
\hline 1 Year Prior & $\begin{array}{l}-0.001 \\
(0.006)\end{array}$ & $\begin{array}{l}-0.002 \\
(0.010)\end{array}$ & $\begin{array}{c}0.005 \\
(0.008)\end{array}$ & $\begin{array}{c}0.007 \\
(0.005)\end{array}$ & $\begin{array}{c}0.004 \\
(0.010)\end{array}$ & $\begin{array}{l}-0.011 \\
(0.006)\end{array}$ \\
\hline Year of law changed & $\begin{array}{c}0.002 \\
(0.006)\end{array}$ & $\begin{array}{l}-0.011 \\
(0.012)\end{array}$ & $\begin{array}{c}0.009 \\
(0.008)\end{array}$ & $\begin{array}{c}0.003 \\
(0.007)\end{array}$ & $\begin{array}{c}0.008 \\
(0.010)\end{array}$ & $\begin{array}{l}-0.005 \\
(0.006)\end{array}$ \\
\hline 1 Year After & $\begin{array}{c}0.003 \\
(0.004)\end{array}$ & $\begin{array}{c}0.004 \\
(0.014)\end{array}$ & $\begin{array}{c}0.002 \\
(0.006)\end{array}$ & $\begin{array}{c}0.010 \\
(0.007)\end{array}$ & $\begin{array}{c}0.011 \\
(0.007)\end{array}$ & $\begin{array}{l}-0.006 \\
(0.005)\end{array}$ \\
\hline 2 Years After & $\begin{array}{c}0.005 \\
(0.006)\end{array}$ & $\begin{array}{c}0.032 \\
(0.017)\end{array}$ & $\begin{array}{c}0.010 \\
(0.010)\end{array}$ & $\begin{array}{c}0.008 \\
(0.006)\end{array}$ & $\begin{array}{c}0.006 \\
(0.007)\end{array}$ & $\begin{array}{l}-0.003 \\
(0.006)\end{array}$ \\
\hline $3+$ Years After & $\begin{array}{c}0.010 \\
(0.008)\end{array}$ & $\begin{array}{c}0.013 \\
(0.013)\end{array}$ & $\begin{array}{c}0.018 \\
(0.009)\end{array}$ & $\begin{array}{c}0.014 \\
(0.007)\end{array}$ & $\begin{array}{c}0.016 \\
(0.011)\end{array}$ & $\begin{array}{l}-0.000 \\
(0.008)\end{array}$ \\
\hline$\chi^{2}$ of $\sum\left(\beta_{\text {leads }}\right)=0$ & 0.607 & 0.348 & 1.011 & 3.273 & 0.894 & 0.123 \\
\hline p-value & 0.44 & 0.558 & 0.32 & 0.076 & 0.349 & 0.728 \\
\hline$\chi^{2}$ of $\sum\left(\beta_{\text {yrchange, }} \beta_{\text {lags }}\right)=0$ & 1.027 & 1.039 & 2.032 & 3.051 & 1.598 & 0.557 \\
\hline
\end{tabular}




\begin{tabular}{|c|c|c|c|c|c|c|}
\hline & $\begin{array}{c}\text { All } \\
\text { Ages }\end{array}$ & $\begin{array}{c}\text { Ages } \\
\text { 18-to-19 }\end{array}$ & $\begin{array}{c}\text { Ages } \\
\text { 20-to-29 }\end{array}$ & $\begin{array}{c}\text { Ages } \\
\text { 30-to-39 }\end{array}$ & $\begin{array}{c}\text { Ages } \\
40-\text { to- } 49\end{array}$ & $\begin{array}{c}\text { Ages } \\
50-\text { to-64 }\end{array}$ \\
\hline p-value & 0.316 & 0.313 & 0.16 & 0.087 & 0.212 & 0.459 \\
\hline $\mathrm{N}$ & $2,979,660$ & 130,858 & 621,919 & 700,506 & 713,095 & 813,282 \\
\hline & \multicolumn{6}{|c|}{ Panel III: Females } \\
\hline 4 Years Prior & $\begin{array}{l}-0.001 \\
(0.002)\end{array}$ & $\begin{array}{c}0.000 \\
(0.010)\end{array}$ & $\begin{array}{c}0.005 \\
(0.003)\end{array}$ & $\begin{array}{l}-0.007 \\
(0.004)\end{array}$ & $\begin{array}{l}-0.008 \\
(0.004)\end{array}$ & $\begin{array}{c}0.006 \\
(0.006)\end{array}$ \\
\hline 3 Years Prior & $\begin{array}{l}-0.003 \\
(0.003)\end{array}$ & $\begin{array}{c}0.013 \\
(0.013)\end{array}$ & $\begin{array}{c}0.002 \\
(0.005)\end{array}$ & $\begin{array}{l}-0.009 \\
(0.006)\end{array}$ & $\begin{array}{c}-0.012^{*} \\
(0.006)\end{array}$ & $\begin{array}{c}0.005 \\
(0.005)\end{array}$ \\
\hline 2 Years Prior & $\begin{array}{l}-0.001 \\
(0.003)\end{array}$ & $\begin{array}{c}0.004 \\
(0.018)\end{array}$ & $\begin{array}{l}-0.005 \\
(0.006)\end{array}$ & $\begin{array}{l}-0.007 \\
(0.005)\end{array}$ & $\begin{array}{c}0.004 \\
(0.007)\end{array}$ & $\begin{array}{c}0.002 \\
(0.005)\end{array}$ \\
\hline 1 Year Prior & $\begin{array}{l}-0.005 \\
(0.004)\end{array}$ & $\begin{array}{l}-0.004 \\
(0.017)\end{array}$ & $\begin{array}{l}-0.004 \\
(0.008)\end{array}$ & $\begin{array}{l}-0.012 \\
(0.006)\end{array}$ & $\begin{array}{c}0.005 \\
(0.004)\end{array}$ & $\begin{array}{l}-0.005 \\
(0.007)\end{array}$ \\
\hline Year of law changed & $\begin{array}{l}-0.001 \\
(0.005)\end{array}$ & $\begin{array}{l}-0.002 \\
(0.015)\end{array}$ & $\begin{array}{c}0.007 \\
(0.008)\end{array}$ & $\begin{array}{l}-0.014 \\
(0.008)\end{array}$ & $\begin{array}{l}-0.002 \\
(0.005)\end{array}$ & $\begin{array}{c}0.002 \\
(0.007)\end{array}$ \\
\hline 1 Year After & $\begin{array}{c}0.001 \\
(0.006)\end{array}$ & $\begin{array}{l}-0.002 \\
(0.016)\end{array}$ & $\begin{array}{c}0.007 \\
(0.006)\end{array}$ & $\begin{array}{l}-0.008 \\
(0.008)\end{array}$ & $\begin{array}{l}-0.000 \\
(0.008)\end{array}$ & $\begin{array}{l}-0.001 \\
(0.008)\end{array}$ \\
\hline 2 Years After & $\begin{array}{l}-0.006 \\
(0.006)\end{array}$ & $\begin{array}{c}0.000 \\
(0.019)\end{array}$ & $\begin{array}{l}-0.002 \\
(0.008)\end{array}$ & $\begin{array}{l}-0.009 \\
(0.008)\end{array}$ & $\begin{array}{l}-0.014 \\
(0.007)\end{array}$ & $\begin{array}{c}-0.003 \\
(0.011)\end{array}$ \\
\hline $3+$ Years After & $\begin{array}{c}0.000 \\
(0.006)\end{array}$ & $\begin{array}{c}0.021 \\
(0.018)\end{array}$ & $\begin{array}{c}0.008 \\
(0.008)\end{array}$ & $\begin{array}{l}-0.001 \\
(0.007)\end{array}$ & $\begin{array}{l}-0.008 \\
(0.007)\end{array}$ & $\begin{array}{l}-0.004 \\
(0.009)\end{array}$ \\
\hline$\chi^{2}$ of $\sum\left(\beta_{\text {leads }}\right)=0$ & 0.935 & 0.086 & 0.008 & 4.638 & 0.56 & 0.166 \\
\hline p-value & 0.338 & 0.771 & 0.928 & 0.036 & 0.458 & 0.685 \\
\hline$\chi^{2}$ of $\sum\left(\beta_{\text {yrchange, }}, \beta_{\text {lags }}\right)=0$ & 0.081 & 0.1 & 0.697 & 1.86 & 1.036 & 0.023 \\
\hline p-value & 0.777 & 0.753 & 0.408 & 0.179 & 0.314 & 0.879 \\
\hline $\mathrm{N}$ & $3,209,947$ & 129,391 & 667,336 & 764,063 & 767,403 & 881,754 \\
\hline
\end{tabular}

**Significant at $1 \%$ level * at $5 \%$ level

Notes: Weighted OLS estimates are obtained using data from the 1990 to 2014 Current Population Survey Outgoing Rotation Groups. All regressions include state fixed effects, year fixed effects and state specific linear time trends. Demographic controls include gender, race/ethnicity, age (linear and squared)/potential experience (linear and squared), education, marital status, industry classification, and whether the respondent enrolls in school. State level policy and economic controls include marijuana decriminalization laws, state level alcohol and cigarette taxes, minimum wages, and per capita GDP. Standard errors corrected for clustering on the state are in parentheses. 
Appendix Table 8. Robustness of Estimates of the Effect of MMLs on Log Hours to Controls for Policy Leads and Lags

\begin{tabular}{|c|c|c|c|c|c|c|}
\hline & $\begin{array}{c}\text { All } \\
\text { Ages }\end{array}$ & $\begin{array}{c}\text { Ages } \\
\text { 18-to-19 }\end{array}$ & $\begin{array}{c}\text { Ages } \\
\text { 20-to-29 }\end{array}$ & $\begin{array}{c}\text { Ages } \\
\text { 30-to-39 }\end{array}$ & $\begin{array}{c}\text { Ages } \\
\text { 40-to-49 }\end{array}$ & $\begin{array}{c}\text { Ages } \\
50-t 0-64 \\
\end{array}$ \\
\hline & \multicolumn{6}{|c|}{ Panel I: Pooled Sample } \\
\hline \multirow[t]{2}{*}{4 Years Prior } & 0.001 & -0.001 & -0.005 & 0.001 & $0.004^{*}$ & 0.001 \\
\hline & $(0.002)$ & $(0.010)$ & $(0.005)$ & $(0.003)$ & $(0.002)$ & $(0.003)$ \\
\hline \multirow[t]{2}{*}{3 Years Prior } & -0.001 & 0.007 & -0.006 & -0.004 & 0.004 & 0.000 \\
\hline & $(0.003)$ & $(0.013)$ & $(0.003)$ & $(0.002)$ & $(0.003)$ & $(0.005)$ \\
\hline \multirow[t]{2}{*}{2 Years Prior } & -0.001 & -0.008 & -0.007 & 0.001 & -0.003 & 0.002 \\
\hline & $(0.002)$ & $(0.014)$ & $(0.004)$ & $(0.003)$ & $(0.004)$ & $(0.004)$ \\
\hline \multirow[t]{2}{*}{1 Year Prior } & -0.002 & -0.008 & -0.005 & 0.001 & -0.004 & -0.001 \\
\hline & $(0.001)$ & $(0.015)$ & $(0.004)$ & $(0.002)$ & $(0.003)$ & $(0.004)$ \\
\hline \multirow[t]{2}{*}{ Year of law changed } & -0.000 & -0.013 & -0.004 & 0.001 & -0.001 & 0.001 \\
\hline & $(0.002)$ & $(0.017)$ & $(0.004)$ & $(0.003)$ & $(0.003)$ & $(0.002)$ \\
\hline \multirow[t]{2}{*}{1 Year After } & 0.001 & $0.042^{*}$ & 0.003 & -0.002 & 0.002 & -0.005 \\
\hline & $(0.002)$ & $(0.020)$ & $(0.004)$ & $(0.003)$ & $(0.003)$ & $(0.004)$ \\
\hline \multirow[t]{2}{*}{2 Years After } & -0.002 & 0.006 & -0.000 & $-0.006^{*}$ & -0.002 & -0.002 \\
\hline & $(0.002)$ & $(0.015)$ & $(0.003)$ & $(0.003)$ & $(0.002)$ & $(0.006)$ \\
\hline \multirow[t]{2}{*}{$3+$ Years After } & 0.004 & 0.034 & 0.000 & -0.001 & 0.006 & 0.002 \\
\hline & $(0.002)$ & $(0.019)$ & $(0.005)$ & $(0.003)$ & $(0.003)$ & $(0.003)$ \\
\hline$\chi^{2}$ of $\sum\left(\beta_{\text {leads }}\right)=0$ & 0.26 & 0.081 & 4.253 & 0.007 & 0.042 & 0.037 \\
\hline p-value & 0.613 & 0.777 & 0.044 & 0.934 & 0.839 & 0.847 \\
\hline$\chi^{2}$ of $\sum\left(\beta_{\text {yrchange, }} \beta_{\text {lags }}\right)=0$ & 0.180 & 1.994 & 0.019 & 1.220 & 0.498 & 0.232 \\
\hline p-value & 0.673 & 0.164 & 0.890 & 0.275 & 0.484 & 0.632 \\
\hline \multirow[t]{2}{*}{$\mathrm{N}$} & $3,830,355$ & 114,498 & 851,953 & 997,335 & 983,448 & 883,121 \\
\hline & \multicolumn{6}{|c|}{ Panel II: Males } \\
\hline \multirow[t]{2}{*}{4 Years Prior } & -0.001 & 0.005 & -0.003 & -0.002 & 0.001 & -0.001 \\
\hline & $(0.002)$ & $(0.014)$ & $(0.006)$ & $(0.003)$ & $(0.003)$ & $(0.005)$ \\
\hline \multirow[t]{2}{*}{3 Years Prior } & -0.002 & -0.012 & -0.005 & -0.001 & -0.002 & 0.000 \\
\hline & $(0.002)$ & $(0.021)$ & $(0.004)$ & $(0.003)$ & $(0.003)$ & $(0.005)$ \\
\hline \multirow[t]{2}{*}{2 Years Prior } & $-0.004 *$ & 0.000 & $-0.010 * *$ & -0.004 & $-0.007 *$ & 0.003 \\
\hline & $(0.002)$ & $(0.024)$ & $(0.004)$ & $(0.003)$ & $(0.003)$ & $(0.004)$ \\
\hline \multirow[t]{2}{*}{1 Year Prior } & -0.004 & -0.009 & -0.008 & -0.001 & -0.006 & -0.001 \\
\hline & $(0.003)$ & $(0.014)$ & $(0.006)$ & $(0.003)$ & $(0.003)$ & $(0.006)$ \\
\hline \multirow[t]{2}{*}{ Year of law changed } & -0.004 & 0.008 & -0.005 & $-0.006^{*}$ & $-0.007 * *$ & 0.003 \\
\hline & $(0.003)$ & $(0.024)$ & $(0.005)$ & $(0.003)$ & $(0.002)$ & $(0.005)$ \\
\hline \multirow[t]{2}{*}{1 Year After } & -0.002 & 0.021 & -0.000 & -0.005 & -0.003 & -0.002 \\
\hline & $(0.002)$ & $(0.017)$ & $(0.004)$ & $(0.003)$ & $(0.004)$ & $(0.005)$ \\
\hline \multirow[t]{2}{*}{2 Years After } & -0.004 & -0.015 & -0.003 & $-0.009 * *$ & -0.004 & 0.003 \\
\hline & $(0.003)$ & $(0.039)$ & $(0.005)$ & $(0.002)$ & $(0.003)$ & $(0.007)$ \\
\hline \multirow[t]{2}{*}{$3+$ Years After } & 0.002 & 0.038 & 0.001 & -0.002 & -0.001 & 0.006 \\
\hline & $(0.003)$ & $(0.022)$ & $(0.005)$ & $(0.002)$ & $(0.005)$ & $(0.004)$ \\
\hline
\end{tabular}




\begin{tabular}{|c|c|c|c|c|c|c|}
\hline & $\begin{array}{c}\text { All } \\
\text { Ages }\end{array}$ & $\begin{array}{c}\text { Ages } \\
\text { 18-to-19 }\end{array}$ & $\begin{array}{c}\text { Ages } \\
\text { 20-to-29 }\end{array}$ & $\begin{array}{c}\text { Ages } \\
\text { 30-to-39 }\end{array}$ & $\begin{array}{c}\text { Ages } \\
40-\text { to- } 49\end{array}$ & $\begin{array}{c}\text { Ages } \\
50-\text { to- } 64\end{array}$ \\
\hline$\chi^{2}$ of $\sum\left(\beta_{\text {leads }}\right)=0$ & 3.192 & 0.093 & 3.713 & 0.925 & 3.441 & 0.003 \\
\hline $\mathrm{p}$-value & 0.08 & 0.762 & 0.060 & 0.341 & 0.069 & 0.953 \\
\hline$\chi^{2}$ of $\sum\left(\beta_{\text {yrchange, }}, \beta_{\text {lags }}\right)=0$ & 0.961 & 0.419 & 0.278 & 7.421 & 2.286 & 0.298 \\
\hline p-value & 0.332 & 0.521 & 0.600 & 0.009 & 0.137 & 0.587 \\
\hline $\mathrm{N}$ & $1,938,600$ & 57,158 & 436,154 & 516,955 & 489,409 & 438,924 \\
\hline & \multicolumn{6}{|c|}{ Panel III: Females } \\
\hline 4 Years Prior & $\begin{array}{c}0.002 \\
(0.002)\end{array}$ & $\begin{array}{l}-0.008 \\
(0.015)\end{array}$ & $\begin{array}{c}-0.006 \\
(0.006)\end{array}$ & $\begin{array}{c}0.003 \\
(0.004)\end{array}$ & $\begin{array}{l}0.006^{*} \\
(0.003)\end{array}$ & $\begin{array}{c}0.003 \\
(0.004)\end{array}$ \\
\hline 3 Years Prior & $\begin{array}{c}0.000 \\
(0.004)\end{array}$ & $\begin{array}{c}0.023 \\
(0.021)\end{array}$ & $\begin{array}{l}-0.007 \\
(0.006)\end{array}$ & $\begin{array}{l}-0.008 \\
(0.004)\end{array}$ & $\begin{array}{l}0.010^{*} \\
(0.005)\end{array}$ & $\begin{array}{c}0.000 \\
(0.006)\end{array}$ \\
\hline 2 Years Prior & $\begin{array}{c}0.001 \\
(0.003)\end{array}$ & $\begin{array}{l}-0.016 \\
(0.013)\end{array}$ & $\begin{array}{l}-0.003 \\
(0.007)\end{array}$ & $\begin{array}{c}0.005 \\
(0.004)\end{array}$ & $\begin{array}{c}0.001 \\
(0.006)\end{array}$ & $\begin{array}{c}0.001 \\
(0.006)\end{array}$ \\
\hline 1 Year Prior & $\begin{array}{l}-0.000 \\
(0.002)\end{array}$ & $\begin{array}{l}-0.006 \\
(0.023)\end{array}$ & $\begin{array}{l}-0.002 \\
(0.005)\end{array}$ & $\begin{array}{c}0.001 \\
(0.004)\end{array}$ & $\begin{array}{l}-0.003 \\
(0.005)\end{array}$ & $\begin{array}{l}-0.000 \\
(0.005)\end{array}$ \\
\hline Year of law changed & $\begin{array}{c}0.003 \\
(0.002)\end{array}$ & $\begin{array}{l}-0.033 \\
(0.030)\end{array}$ & $\begin{array}{l}-0.002 \\
(0.005)\end{array}$ & $\begin{array}{c}0.008 \\
(0.004)\end{array}$ & $\begin{array}{c}0.005 \\
(0.004)\end{array}$ & $\begin{array}{l}-0.001 \\
(0.005)\end{array}$ \\
\hline 1 Year After & $\begin{array}{c}0.003 \\
(0.004)\end{array}$ & $\begin{array}{l}0.069^{*} \\
(0.032)\end{array}$ & $\begin{array}{c}0.005 \\
(0.008)\end{array}$ & $\begin{array}{l}-0.001 \\
(0.006)\end{array}$ & $\begin{array}{c}0.005 \\
(0.006)\end{array}$ & $\begin{array}{l}-0.009 \\
(0.005)\end{array}$ \\
\hline 2 Years After & $\begin{array}{l}-0.001 \\
(0.002)\end{array}$ & $\begin{array}{c}0.028 \\
(0.029)\end{array}$ & $\begin{array}{c}0.001 \\
(0.005)\end{array}$ & $\begin{array}{l}-0.004 \\
(0.005)\end{array}$ & $\begin{array}{l}-0.003 \\
(0.005)\end{array}$ & $\begin{array}{l}-0.008 \\
(0.006)\end{array}$ \\
\hline $3+$ Years After & $\begin{array}{c}0.004 \\
(0.003)\end{array}$ & $\begin{array}{c}0.032 \\
(0.025)\end{array}$ & $\begin{array}{l}-0.001 \\
(0.008)\end{array}$ & $\begin{array}{l}-0.002 \\
(0.006)\end{array}$ & $\begin{array}{l}0.012^{*} \\
(0.005)\end{array}$ & $\begin{array}{l}-0.003 \\
(0.005)\end{array}$ \\
\hline$\chi^{2}$ of $\sum\left(\beta_{\text {leads }}\right)=0$ & 0.073 & 0.026 & 2.286 & 0.016 & 0.934 & 0.065 \\
\hline $\mathrm{p}$-value & 0.788 & 0.873 & 0.137 & 0.899 & 0.338 & 0.800 \\
\hline$\chi^{2}$ of $\sum\left(\beta_{\text {yrchange, }}, \beta_{\text {lags }}\right)=0$ & 2.338 & 0.877 & 0.022 & 0.02 & 1.437 & 2.175 \\
\hline p-value & 0.133 & 0.353 & 0.881 & 0.889 & 0.236 & 0.147 \\
\hline $\mathrm{N}$ & $1,891,755$ & 57,340 & 415,799 & 480,380 & 494,039 & 444,197 \\
\hline
\end{tabular}

** Significant at $1 \%$ level * at $5 \%$ level

Notes: Weighted OLS estimates are obtained using data from the 1990 to 2014 Current Population Survey Outgoing Rotation Groups. All regressions include state fixed effects, year fixed effects and state specific linear time trends. Demographic controls include gender, race/ethnicity, age (linear and squared)/potential experience (linear and squared), education, marital status, industry classification, and whether the respondent enrolls in school. State level policy and economic controls include marijuana decriminalization laws, state level alcohol and cigarette taxes, minimum wages, and per capita GDP. Standard errors corrected for clustering on the state are in parentheses. 
Appendix Table 9. State Weights Implied by Synthetic Control Method

\begin{tabular}{|c|c|c|c|c|c|c|c|c|c|c|c|c|c|c|c|c|c|c|c|c|c|}
\hline & AL & AR & FL & ID & IN & $\mathbf{K Y}$ & LA & MO & NC & ND & $\mathrm{OH}$ & OK & PA & SC & SD & TX & UT & VA & WI & WV & WY \\
\hline$A K$ & $\ldots$ & $\ldots$ & $\ldots$ & $\ldots$ & $\ldots$ & $\ldots$ & $\ldots$ & $\ldots$ & $\ldots$ & $\ldots$ & $\ldots$ & $\ldots$ & $\ldots$ & $\ldots$ & $\ldots$ & $\ldots$ & $\ldots$ & 0.981 & $\ldots$ & $\ldots$ & 0.019 \\
\hline$A Z$ & $\ldots$ & $\ldots$ & 0.693 & $\ldots$ & $\ldots$ & $\ldots$ & $\ldots$ & $\ldots$ & $\ldots$ & 0.017 & $\ldots$ & 0.132 & $\ldots$ & $\ldots$ & $\ldots$ & 0.022 & 0.104 & $\ldots$ & $\ldots$ & $\ldots$ & 0.032 \\
\hline$C A$ & $\ldots$ & $\ldots$ & $\ldots$ & $\ldots$ & $\ldots$ & $\ldots$ & $\ldots$ & $\ldots$ & $\ldots$ & $\ldots$ & $\ldots$ & 0.183 & 0.224 & $\ldots$ & $\ldots$ & $\ldots$ & $\ldots$ & 0.592 & $\ldots$ & $\ldots$ & $\ldots$ \\
\hline$C O$ & $\ldots$ & $\ldots$ & $\ldots$ & $\ldots$ & $\ldots$ & $\ldots$ & $\ldots$ & 0.362 & $\ldots$ & $\ldots$ & 0.279 & $\ldots$ & $\ldots$ & $\ldots$ & $\ldots$ & $\ldots$ & $\ldots$ & 0.207 & 0.152 & $\ldots$ & $\ldots$ \\
\hline$C T$ & $\ldots$ & $\ldots$ & $\ldots$ & $\ldots$ & $\ldots$ & $\ldots$ & $\ldots$ & $\ldots$ & $\ldots$ & $\ldots$ & $\ldots$ & $\ldots$ & 0.679 & $\ldots$ & $\ldots$ & $\ldots$ & $\ldots$ & 0.321 & $\ldots$ & $\ldots$ & $\ldots$ \\
\hline$D E$ & $\ldots$ & $\ldots$ & $\ldots$ & $\ldots$ & $\ldots$ & $\ldots$ & $\ldots$ & $\ldots$ & $\ldots$ & $\ldots$ & $\ldots$ & $\ldots$ & $\ldots$ & $\ldots$ & $\ldots$ & $\ldots$ & $\ldots$ & 0.807 & 0.142 & $\ldots$ & 0.051 \\
\hline$D C$ & $\ldots$ & $\ldots$ & $\ldots$ & $\ldots$ & $\ldots$ & $\ldots$ & $\ldots$ & $\ldots$ & $\ldots$ & $\ldots$ & $\ldots$ & $\ldots$ & $\ldots$ & $\ldots$ & $\ldots$ & $\ldots$ & $\ldots$ & 1.000 & $\ldots$ & $\ldots$ & $\ldots$ \\
\hline$H I$ & $\ldots$ & $\ldots$ & $\ldots$ & $\ldots$ & $\ldots$ & $\ldots$ & $\ldots$ & $\ldots$ & $\ldots$ & $\ldots$ & $\ldots$ & $\ldots$ & 1.000 & $\ldots$ & $\ldots$ & $\ldots$ & $\ldots$ & $\ldots$ & $\ldots$ & $\ldots$ & $\ldots$ \\
\hline$I L$ & $\ldots$ & $\ldots$ & $\ldots$ & $\ldots$ & $\ldots$ & $\ldots$ & $\ldots$ & $\ldots$ & $\ldots$ & $\ldots$ & $\ldots$ & $\ldots$ & 0.377 & $\ldots$ & $\ldots$ & $\ldots$ & $\ldots$ & 0.623 & $\ldots$ & $\ldots$ & $\ldots$ \\
\hline$M E$ & 0.316 & $\ldots$ & 0.105 & 0.148 & $\ldots$ & $\ldots$ & $\ldots$ & $\ldots$ & $\ldots$ & $\ldots$ & $\ldots$ & 0.031 & 0.319 & 0.060 & 0.020 & $\ldots$ & $\ldots$ & $\ldots$ & $\ldots$ & $\ldots$ & $\ldots$ \\
\hline$M D$ & $\ldots$ & $\ldots$ & 0.294 & $\ldots$ & $\ldots$ & $\ldots$ & $\ldots$ & $\ldots$ & $\ldots$ & $\ldots$ & $\ldots$ & $\ldots$ & $\ldots$ & $\ldots$ & $\ldots$ & $\ldots$ & $\ldots$ & 0.701 & $\ldots$ & $\ldots$ & 0.006 \\
\hline$M A$ & $\ldots$ & $\ldots$ & $\ldots$ & $\ldots$ & $\ldots$ & $\ldots$ & $\ldots$ & $\ldots$ & $\ldots$ & $\ldots$ & $\ldots$ & $\ldots$ & $\ldots$ & $\ldots$ & $\ldots$ & $\ldots$ & $\ldots$ & 1.000 & $\ldots$ & $\ldots$ & $\ldots$ \\
\hline$M I$ & $\ldots$ & $\ldots$ & $\ldots$ & $\ldots$ & $\ldots$ & $\ldots$ & $\ldots$ & $\ldots$ & $\ldots$ & $\ldots$ & 0.235 & $\ldots$ & 0.296 & $\ldots$ & $\ldots$ & $\ldots$ & $\ldots$ & $\ldots$ & 0.469 & $\ldots$ & $\ldots$ \\
\hline$M N$ & $\ldots$ & $\ldots$ & $\ldots$ & $\ldots$ & $\ldots$ & $\ldots$ & $\ldots$ & $\ldots$ & $\ldots$ & $\ldots$ & 0.008 & $\ldots$ & 0.291 & $\ldots$ & $\ldots$ & $\ldots$ & $\ldots$ & 0.636 & 0.065 & $\ldots$ & $\ldots$ \\
\hline$M T$ & $\ldots$ & 0.214 & $\ldots$ & $\ldots$ & $\ldots$ & 0.093 & $\ldots$ & $\ldots$ & $\ldots$ & 0.291 & $\ldots$ & $\ldots$ & $\ldots$ & $\ldots$ & 0.294 & $\ldots$ & $\ldots$ & $\ldots$ & $\ldots$ & $\ldots$ & 0.108 \\
\hline$N V$ & $\ldots$ & $\ldots$ & $\ldots$ & $\ldots$ & $\ldots$ & $\ldots$ & $\ldots$ & $\ldots$ & $\ldots$ & $\ldots$ & $\ldots$ & $\ldots$ & 0.794 & $\ldots$ & $\ldots$ & $\ldots$ & $\ldots$ & 0.206 & $\ldots$ & $\ldots$ & $\ldots$ \\
\hline $\mathrm{NH}$ & $\ldots$ & $\ldots$ & $\ldots$ & $\ldots$ & 0.051 & $\ldots$ & $\ldots$ & $\ldots$ & $\ldots$ & $\ldots$ & $\ldots$ & $\ldots$ & $\ldots$ & $\ldots$ & $\ldots$ & $\ldots$ & $\ldots$ & 0.498 & 0.451 & $\ldots$ & $\ldots$ \\
\hline$N J$ & $\ldots$ & $\ldots$ & $\ldots$ & $\ldots$ & $\ldots$ & $\ldots$ & $\ldots$ & $\ldots$ & $\ldots$ & $\ldots$ & $\ldots$ & $\ldots$ & 0.512 & $\ldots$ & $\ldots$ & $\ldots$ & $\ldots$ & 0.488 & $\ldots$ & $\ldots$ & $\ldots$ \\
\hline$N M$ & $\ldots$ & $\ldots$ & $\ldots$ & $\ldots$ & $\ldots$ & $\ldots$ & $\ldots$ & $\ldots$ & $\ldots$ & 0.286 & $\ldots$ & 0.012 & $\ldots$ & $\ldots$ & 0.234 & 0.467 & $\ldots$ & $\ldots$ & $\ldots$ & $\ldots$ & $\ldots$ \\
\hline$N Y$ & $\ldots$ & $\ldots$ & $\ldots$ & $\ldots$ & $\ldots$ & $\ldots$ & $\ldots$ & $\ldots$ & $\ldots$ & $\ldots$ & $\ldots$ & $\ldots$ & 0.209 & $\ldots$ & $\ldots$ & $\ldots$ & $\ldots$ & 0.791 & $\ldots$ & $\ldots$ & $\ldots$ \\
\hline$O R$ & $\ldots$ & 0.055 & $\ldots$ & 0.154 & 0.018 & $\ldots$ & $\ldots$ & $\ldots$ & 0.236 & $\ldots$ & $\ldots$ & $\ldots$ & 0.444 & $\ldots$ & $\ldots$ & $\ldots$ & $\ldots$ & $\ldots$ & 0.093 & $\ldots$ & $\ldots$ \\
\hline$R I$ & $\ldots$ & $\ldots$ & $\ldots$ & $\ldots$ & $\ldots$ & $\ldots$ & $\ldots$ & $\ldots$ & $\ldots$ & $\ldots$ & 0.114 & $\ldots$ & 0.886 & $\ldots$ & $\ldots$ & $\ldots$ & $\ldots$ & $\ldots$ & $\ldots$ & $\ldots$ & $\ldots$ \\
\hline$V T$ & $\ldots$ & $\ldots$ & $\ldots$ & $\ldots$ & $\ldots$ & $\ldots$ & 0.118 & $\ldots$ & $\ldots$ & $\ldots$ & $\ldots$ & $\ldots$ & 0.682 & $\ldots$ & 0.036 & $\ldots$ & $\ldots$ & $\ldots$ & $\ldots$ & 0.011 & 0.153 \\
\hline WA & $\ldots$ & $\ldots$ & $\ldots$ & $\ldots$ & $\ldots$ & $\ldots$ & $\ldots$ & $\ldots$ & $\ldots$ & $\ldots$ & $\ldots$ & $\ldots$ & 0.323 & $\ldots$ & $\ldots$ & $\ldots$ & $\ldots$ & 0.517 & 0.160 & $\ldots$ & $\ldots$ \\
\hline
\end{tabular}

